\title{
A Geological Perspective on Climate Change and Building Stone Deterioration in London: Implications for Urban Stone-Built Heritage Research and Management
}

\author{
Sudeshna Basu ${ }^{1,2, *}$, Scott Allan Orr ${ }^{3}$ (D) and Yasemin D. Aktas ${ }^{4,5}$ (D) \\ 1 Department of Earth Sciences, University College London, 5 Gower Place, London WC1E 6BS, UK \\ 2 Department of Chemical Engineering, University College London, Bloomsbury, London WC1E 7JE, UK \\ 3 Institute for Sustainable Heritage, University College London, Central House, 14 Upper Woburn Place, \\ London WC1H 0NN, UK; scott.orr@ucl.ac.uk \\ 4 Department of Civil, Environmental and Geomatic Engineering, Kings Cross, London WC1E 6DE, UK; \\ y.aktas@ucl.ac.uk \\ 5 UK Centre for Moisture in Buildings (UKCMB), London WC1H 0NN, UK \\ * Correspondence: sudeshna.basu@ucl.ac.uk
}

Received: 1 June 2020; Accepted: 21 July 2020; Published: 26 July 2020

check for updates

\begin{abstract}
The decay rates of building stones and, the processes leading to their deterioration is governed by intrinsic properties such as texture, mineralogy, porosity and pore size distribution, along with other extrinsic factors related to the climate and anthropogenic activities. For urban cities such as London, the influence of extrinsic factors like temperature and rainfall, as well as the concentrations of air pollutants, such as sulphur and nitrogen oxides, along with the emissions of carbonaceous aerosols, can be particularly significant. While considering the long-term preservation of building stones used in various heritage sites in the city, it is imperative to consider how the stone could be affected by the changing air pollutant concentrations, superimposed on the effects of climate change in the region, including rising average annual temperature and precipitation with a hotter, drier summer and, warmer, wetter winter months. This paper deals with the intrinsic rock properties of the common building stones of London, including limestone, marble, granite, sandstone, slate, flint as well as bricks, building on known characteristics including strength and durability that determine how and where they are placed in a building structure. The study reviews how these stones decay due to different processes such as salt weathering in sandstone, microcracking of quartz with kaolinisation of K-feldspar and biotite in granite and dissolution of calcite and dolomite, followed by precipitation of sulphate minerals in the carbonate rocks of limestone and marble. In the urban environment of London, with progressive build up in the concentration of atmospheric nitrogen oxides leading to an increasingly acidic environment and, with predicted climate change, the diverse stone-built heritage will be affected. For example, there can be enhanced carbonate dissolution in limestone with increased annual precipitation. Due to the prolonged wetter winter, any sandstone building stone will also undergo greater damage with a deeper wetting front. On the other hand, due to predicted wetter and warmer winter months, microcracking of any plagioclase in a granite is unlikely, thereby reducing the access of fluid and air pollutants to the Ca-rich core of the zoned crystals limiting the process of sericitisation. Management of the building stones in London should include routine expert visual inspection for signs of deterioration, along with mineralogical and compositional analyses and assessment of any recession rate.
\end{abstract}

Keywords: heritage buildings; lithotype; salt weathering; kaolinisation; microcracking; weather events 


\section{Introduction}

The heritage buildings in any city are important as landmarks, creating a sense of identity, integrated with local history and values, often attesting to the geological substrate on which they stand. While globally, modern buildings are predominantly composed of concrete, the building stones of the heritage sites are both compositionally and structurally distinct. Some may be quarried locally and used over a sustained period of time in a given place or region, and referred to as traditional stone with proximity, the main determinant of its use. However, for cities such as London, which stands on underlying sand, gravel and clay which are poorly consolidated and unsuitable as building stones, building stones are mostly procured from other parts of the UK as well as abroad.

The building stones undergo decay affecting their structural integrity, external fabric and the internal environment as a consequence of the natural patterns of rock weathering depending on their intrinsic properties. These are superimposed by additional conditions and factors including the structure of the building and the urban climate. Once placed in a structure, the pattern of their natural decay is altered, influenced by the degree of exposure to sun, wind and the rain affecting their cycles of wetting, drying, heating and cooling. All these in combination, will either result in acceleration or retardation of the decay processes, affecting how well they can be preserved over time. In the current scenario with climate change being one of the greatest challenges facing the world, the management of buildings, both modern and historic, must consider it to ensure their long-term preservation, including planning an appropriate regime of intervention. A notable difference between modern and historic buildings is that, while the former has an expected design life of 20 to 100 years (although used much longer), the latter can be hundreds of years old. The threat posed to cultural heritage by potential climate change effects can be direct, influenced by extreme weather and environmental conditions. It can also be indirect, affecting the social and economic structures in which they are embedded, for example, by affecting the numerous jobs centred around the cultural tourism sector if these heritage sites undergo degradation [1].

Climate change is manifested as an event related to weather or climate persisting for a longer duration than usual and/or, when they differ from average weather and/or climate events, sometimes with significant changes in trends [2,3]. In the past, it was largely due to natural causes, including variations in the Earth's orbit, ocean currents and volcanic eruptions [4], but today is accelerated due to anthropogenic activity. Taking into account different scenarios to estimate future greenhouse gas emissions, climate models have been developed. For the UK, climate change modelling predicts warmer and wetter winters, hotter and drier summers with increased summer temperature maxima, extreme rainfall events and intensification of the urban heat island effect for the future [5]. Some of the predicted trends for temperature and precipitation are summarised in Figure 1. A mean annual increase in temperature of $0.3^{\circ} \mathrm{C}$ and $0.9^{\circ} \mathrm{C}$ for England between 2008-2017, from 1981-2010 and 1961-1990, respectively, are observed. During the same time period, it has been wetter by 4 to $11 \%$ in terms of the annual average rainfall. Based on the report, projected temperature estimates using probabilistic projections from 1981-2000 to 2080-2099 for the UK region, taking into account a high greenhouse gas emission scenario, lie between 5.7 to $6.3^{\circ} \mathrm{C}$ [5]. The projected precipitation during the same time period is highly variable, declining by $6 \%$ in summer but increasing by up to $48 \%$ during the winter [5]. Based on the exponential Arrhenius equation between the chemical reaction rate and the temperature, for a rise of ten degrees in temperature, the power of destruction by such reactions due to decomposition of constituent materials in any building site will essentially double [1]. Of the many consequences of wetter winters, one would be an increased growth of mould fungi. In previous studies, overall impacts of climate change on buildings have been considered in terms of any change in stress conditions and potential impacts on material properties such as strength, durability and permeability $[6,7]$. 


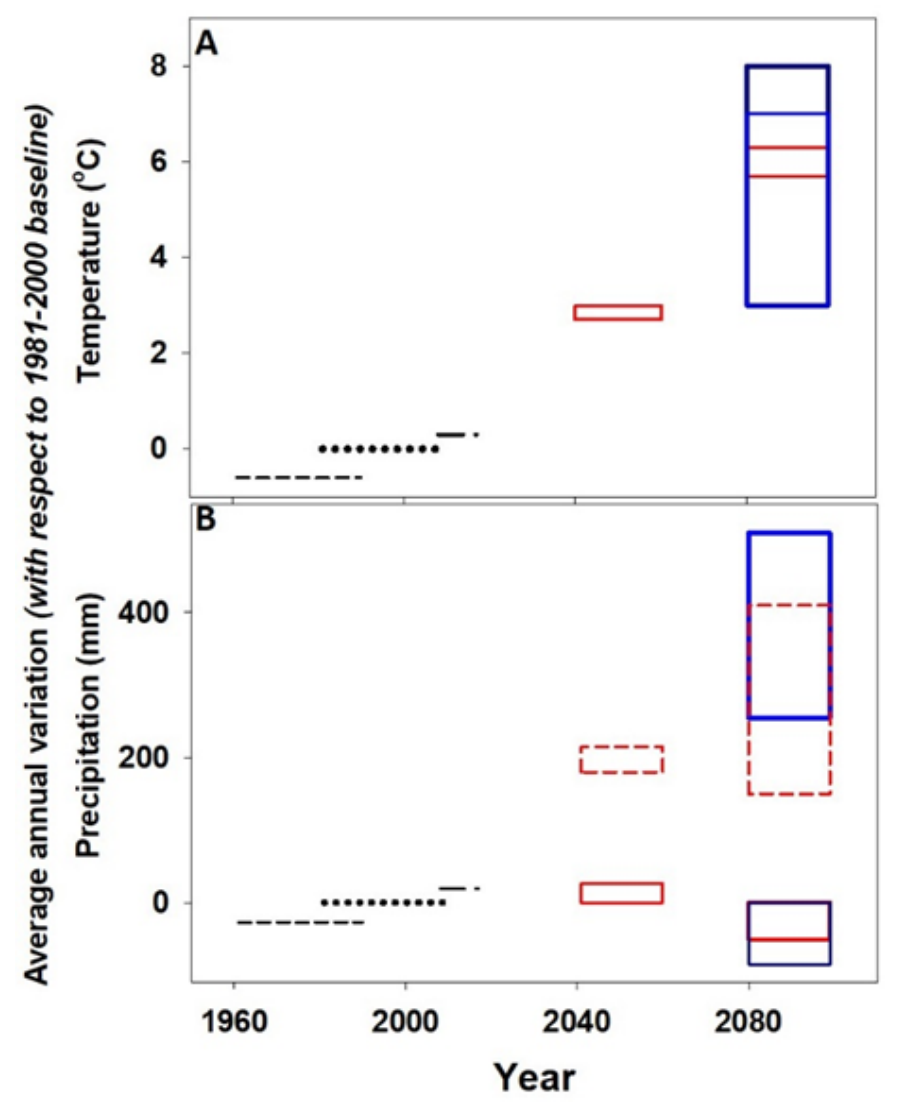

Figure 1. Decadal variation with respect to a baseline of 1981-2000 of annual (A) temperature (B) precipitation marked by dotted (1981-2000), dashed (1961-1981) and dash-dotted (2008-2017) lines, based on UKCP18 projections (Met Office, 2019) [5]. The boxes denote predictions for England (red) and London (blue) with dark and navy for summer and winter, respectively, for London. Solid and dashed boxes mark seasonal projections for summer and winter, respectively, for England. An increase in temperature is observed throughout for England with a predicted significant rise from 2040. This is even more pronounced for London from 2080. A significant increase and decline in precipitation are predicted for London during winter and summer, respectively, towards the end of this century. See text for further discussion.

Climate change and its impacts are more pronounced in large urban areas compared to the global average. In spite of taking up less than 1\% of the Earth's landmass [8], it is well established that cities are the epicentres of long-lived greenhouse gas emissions $[9,10]$. Some of these phenomena, such as the urban heat island, are specific to cities but depend on population size, built area, density and compactness and, regional location. An interplay of anthropogenic impacts such as the energy usage of a city and reemission of energy absorbed by the built environment, depending on the relative distribution of parks, rivers and buildings [11], along with heat absorption/retention, radiation reflection and evapotranspiration properties of prevalent building materials [12], significantly affect not only the temperature, but also the humidity along with the total emissions of air pollution [13]. Based on regional climate model projections for London [5], the temperature increase of 3- $8^{\circ} \mathrm{C}$ during the summers in 2080-2099 from 1981-2000, is higher than the predicted national range of $2.3-6.3^{\circ} \mathrm{C}$ in the same time period (Figure 1). The precipitation decline during the summer can be up to $10 \%$ ( $\sim 85 \mathrm{~mm}$ ) in 2080-2099 from 1981-2000, higher than the 0-6\% (up to $\sim 50 \mathrm{~mm}$ ) expected for England, and would increase by 30-60\% ( 250-500 $\mathrm{mm})$ during the winter, which is significantly higher than the national predicted increase of 18-48\% ( 150-400 mm). These estimates are strongly dependent on future global greenhouse gas emissions and can change in the future depending on methodological and data choices and implementation of the Paris Climate Agreement [14]. 
The deterioration of building stones will be impacted by changes in the concentration of air pollutants over time. As a city expands and its population grows, and if the summer temperature becomes particularly high with low wind conditions, there could be increased concentration of air pollutants from transport emissions while, the dispersal of the pollutants will be affected by the temperature lapse rate within the planetary boundary layer. The traditional pollutants, such as sulphur dioxide and smoke from coal, have decreased since the mid-20th century, with rising traffic related pollutants including nitrogen oxides and particulate matter [15]. Some air pollutants, such as nitrogen oxides, undergo chemical transformation and are often reduced in urban centres while they increase in the outer regions.

Initiatives to make the cities more liveable and "green" may have long-lasting implications for their building stones on one hand. Planting deciduous trees to provide shade in summer, permitting solar gain in winter and usage of thermally reflective surfaces can be viable options to reduce greenhouse gas emissions. Building stones have high thermal masses that should help to soak up unwanted urban heat during the day and regulate temperature better. Based on requirement, mechanical ventilation and cooling need to be installed. To cope with any reduced water infiltration into the ground and any increase in surface run off because of their impervious paving stones, the drainage system needs to be improved. On the other hand, considering the direct environmental effects on the building stones that challenge the resilience of the urban heritage can also help to better preserve our heritage sites.

This paper reviews the possible effects of current and projected trends in extreme weather events in urban areas on a range of building stones used in heritage structures of London. Particular emphasis has been placed on the impacts of climate change phenomena such as precipitation and temperature, the intensity and frequency of which have been modified as a consequence of human activity. Detailed attention has been paid to the different forms of decay, both physical and chemical, such as surface recession and erosion by precipitation, biodeterioration, microcracking and decohesion due to salt crystallisation, that together contribute to the overall deterioration of the stone fabric. The decay processes have been considered in the context of the diverse lithotypes of the building stones as they determine their responses to the changing external environment. Both intrinsic properties of the rocks, as well as the extrinsic attributes such as extreme weather events and pollution, have been considered in tandem to understand any decay of the building stones to the alteration-inducing factors.

\section{Deterioration of Building Materials}

The durability of building stones can be assessed by their ability to resist weathering so that their original size, shape, strength and appearance are retained over an extensive period of time [16]. Rocks weather by a combination of processes including dissolution, salt crystallisation and freeze-thaw activity that are influenced by extrinsic attributes such as meteorological factors and pollution, as well as intrinsic attributes including the petrological and petrophysical properties of the stones. The effect of air pollutants depends strongly on the physical, chemical and mineralogical properties of the lithotypes under consideration as discussed below. The building stones used for important heritage sites in London are listed in Table 1 and shown in Figure 2. 


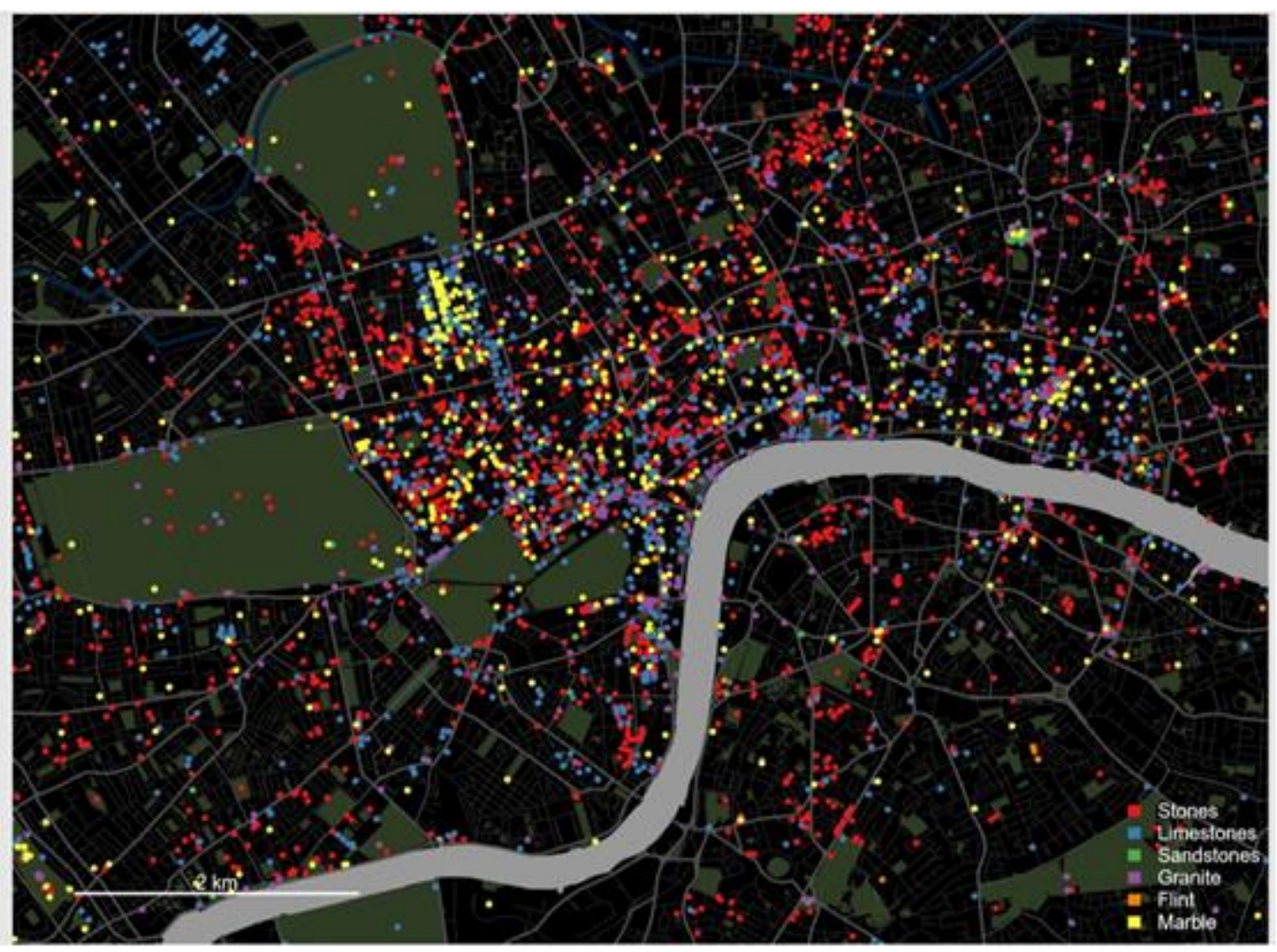

Figure 2. Spatial distribution of common building stones in London including stones (nonspecific), limestone (Portland, Clipsham, Caen and Rag) sandstone (Reigate and others) granite, flint and marble. Portland stone is the most common of the specified varieties.

Table 1. Some of the important heritage sites in London and the building stones used in their construction.

\begin{tabular}{cc}
\hline Heritage Site & Building Stones \\
\hline St Paul's Cathedral & limestone (Portland stone) \\
\hline Buckingham Palace & limestone (Caen); later refaced (Bath Stone) \\
\hline Westminster Abbey & $\begin{array}{c}\text { sandstone (Reigate stone), limestone (Kentish Rag with Purbeck as decorative } \\
\text { columns; refaced with Portland and Yellow Bath stones) and chalk }\end{array}$ \\
\hline White Tower of London & $\begin{array}{c}\text { limestone (Kentish Rag rubblestone, Caen and Quarr) with sandstone } \\
\text { (Reigate stone as upper dressings) }\end{array}$ \\
\hline British Library & $\begin{array}{c}\text { limestone (Hauteville as paving stone; Portland and Purbeck for flooring; } \\
\text { travertine as indoor decorative slabs), granite (Royken granite: facade and steps), } \\
\text { sandstone (outdoor, mounted decorative slab), red bricks (Figures 3 and 4) }\end{array}$ \\
\hline Marble Arch & marble (Carrara) \\
\hline
\end{tabular}

Burlington House, Tower Bridge

British Museum, Somerset House, Bank of England and Mansion House

\begin{tabular}{cc}
\hline New quay and docksides & granite (Cornish and Scottish) and sandstone (Yorkshire) \\
\hline $\begin{array}{c}\text { The Palace of Westminster; New } \\
\text { Houses of Parliament }\end{array}$ & $\begin{array}{c}\text { limestone (originally magnesian limestone, Cadeby Formation, from quarries at } \\
\text { Bolsover Moor and Mansfield; later substituted from the quarries at Anston for }\end{array}$ \\
& most of the upper fabric; \\
& ultimately replaced by Clipsham stone \\
\hline
\end{tabular}

St. Pancras Grand Hotel roofing slates (Leicestershire) and granites (Cumbria) 
Table 1. Cont.

\begin{tabular}{cc}
\hline Heritage Site & Building Stones \\
\hline Southwark Cathedral & flint cobbles in dark mortar with pale stone quoins \\
\hline Trafalgar Square & $\begin{array}{c}\text { granite (Dartmoor: Nelson's column and base; Aberdeen granite: bollards, walls } \\
\text { and statue plinths; Cornish: inlaid strips); limestone (paving); sandstone (red } \\
\text { Mansfield: paving) }\end{array}$ \\
\hline Albert Memorial & $\begin{array}{c}\text { granite (Cornish: walling, steps and lower platform); slates (paving slabs); } \\
\text { limestone (fossiliferous: paving slabs; sandstone (Red Mansfield: paving slabs); } \\
\text { marble (Campanella: statue) }\end{array}$ \\
\hline Big Ben & bricks, limestone (Caen and Anston, in addition to Clipsham for restoration); \\
granite (Cornish)
\end{tabular}

The most commonly used building stones are limestone, marble, sandstone, granite, flint and slate. It is common for a combination of rock types to be used for any particular building, as seen in British Library [17] (Figures 3 and 4) and Tower of London (Figure 5). The properties of these different stones and any related deterioration over time, are discussed below and summarised in Table 2.
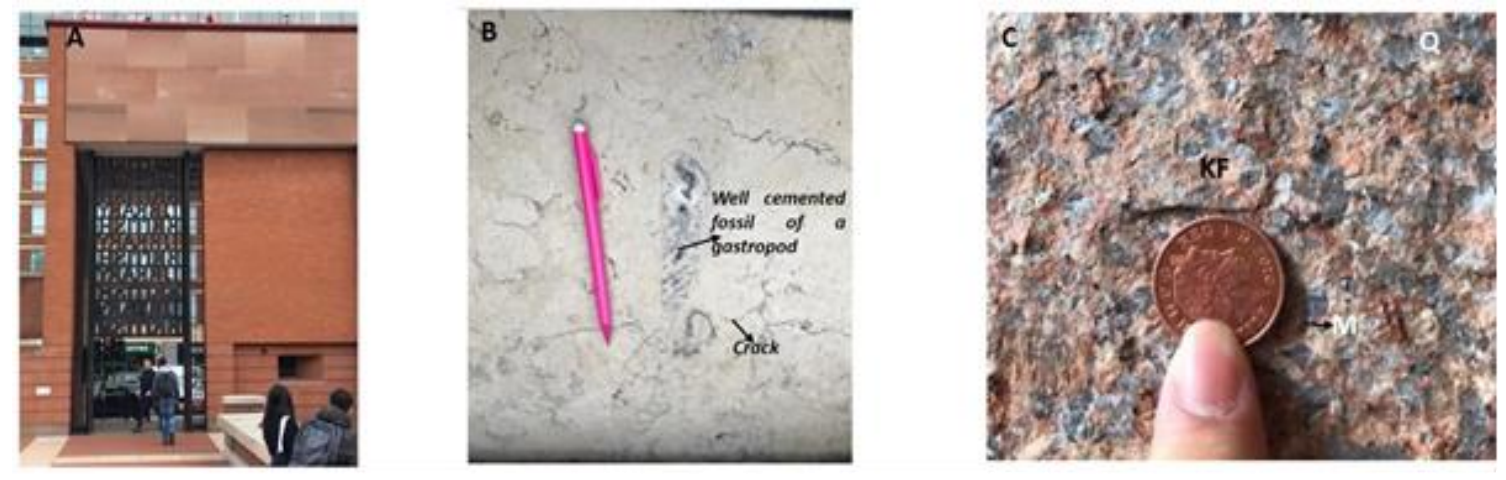

Figure 3. Different building stones used on the British Library exterior, Euston road [17]. (A) Red Sandstone: The red colour, related to its deposition under desert conditions and formation of iron oxide as coatings on the grains makes it aesthetically pleasing. While the pore spaces can provide pathways for water transport and salt deposition, iron oxide acts as a barrier for any reaction with the constituent grains. Laminations are visible, restricting transportation across the layers. Closer inspection is required to comment on its maturity, that will have implications for pore size distribution (unimodal versus bimodal) and consequent ability to transport water by capillary flow. (B) Hauteville Limestone has a crystalline texture and is thereby hard and compact, making it suitable as a paving stone. Compositionally it is homogenous, dominantly made of lime mud which reduces the possibility of differential weathering, except where pits are formed due to preferential removal of uncemented fossil fragments. However, many of the fossil fragments are well cemented, adding to the overall hardness of the rock. The white colour of the rock is partly discoloured to yellow related to salt formation and deposition. The slabs show microcracks due to differential expansion of the carbonate minerals. (C) Royken granite's interlocking mineral grains result in a crystalline texture that gives it compactness and strength, making it suitable for use as a building block for the steps and facade of the library. The reddish colour of the rock can be attributed to the presence of $\sim 60 \%$ potassium feldspar $(\mathrm{KF})$, the most abundant mineral present with quartz $(\mathrm{Q})$ and mica $(\mathrm{M})$. The quartz grains are $\mathrm{mm}$ sized with no visible fissures under hand lenses or naked eyes. The potash feldspar and mica can be prone to kaolinisation and effects of weathering which is evident from the diffused boundaries of the discoloured feldspar. Its finer grain size makes it prone to chemical weathering because of the large surface area available. Differential weathering between the micas and the quartz can leave pits on the exposed rock surfaces. Currently unpolished, however, polishing later can fold and deform the micas if the polishing plane is oblique to the cleavage planes of the micas. 

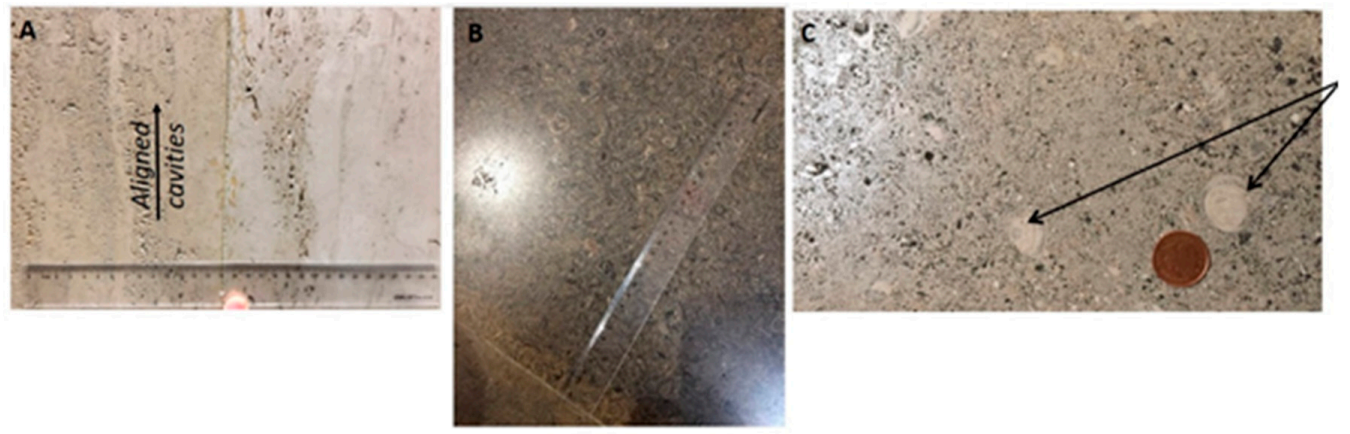

Figure 4. Building stones used in the British Library interior, Euston road [17] including (A) Jura travertine which is a spring deposit from volcanic activity. It is compositionally calcareous, and because of its textural homogeneity, it is advantageously used as a building stone. The macroporosity, arising due to the hollow stems of rushes and plants that flourished in the spring water, attributes a pattern to the rocks due to their alignment and contributes to the total rock porosity while reducing the overall strength of the rock. However, they can still be quite compact where they are structurally massive, lacking bandings and laminations. The macroporous bands act as weak points and, when oriented perpendicular to the load direction, attribute minimum mechanical strength to the building stone [18]. Notably, they do not result in an increase in capillary transport if not connected. At many points, the pore spaces have been infilled with synthetic material to provide a more consistent surface that helps with cleaning. Naturally infiltrated clay minerals result in faint banding adding to the beauty of these stones. (B) Purbeck limestone is highly fossiliferous with abundant fragments of fossil bivalve shells giving it a well patterned appearance. It is dark in colour as deposition occurred under muddy, shallow, freshwater conditions. Because of the hardness, the limestone can be polished and forms a good substitute for more expensive marbles. Cracks are observed but are often cemented. (C) Portland stone is an oolitic limestone, well cemented and compact, and lacks any directional properties making it convenient to cut in all directions. Some calcareous algal pellets are present with some minor oyster shell fragments that have left pits where they were ripped off preferentially by constant foot tread.

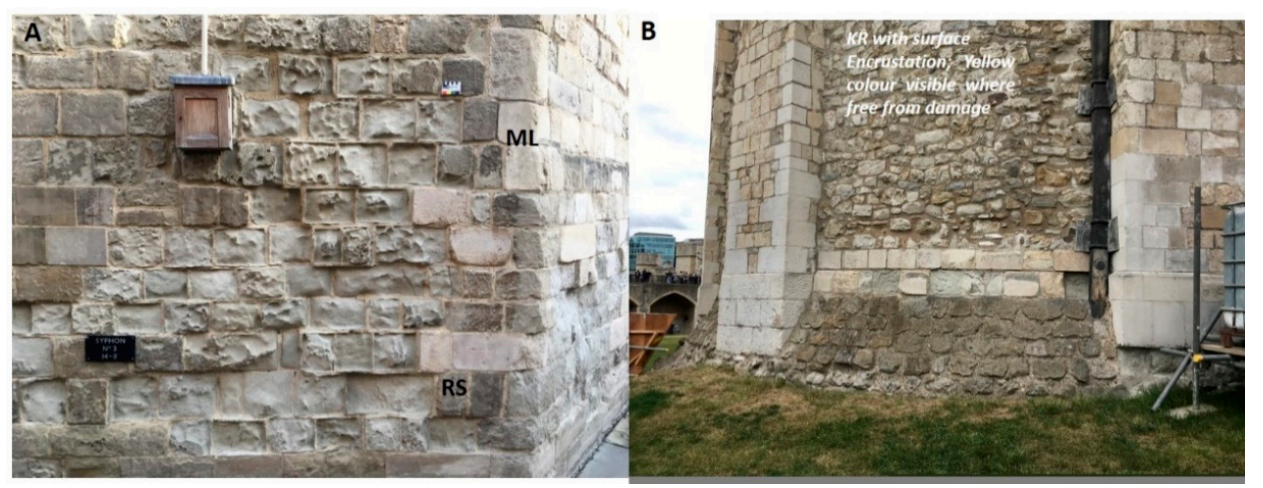

Figure 5. (A) The building stones at the Tower of London including Reigate stone (RS) and magnesian limestone (ML). Although a combination of stones including Caen and Quarr have been used [19], because of surficial damage identifying the individual building stone can be sometimes challenging. (B) The Kentish ragstone (KR) appears damaged with surficial encrustation. Portland stone has been commonly used as replacement blocks identifiable by their sharp boundaries and pale colour. Image credit: Historic Royal Palaces; used with permission.

\subsection{Carbonate Rocks (Limestone and Marble)}

These rocks are comprised of more than $50 \%$ of carbonate minerals. Although they are compositionally uniform, their physical characteristics such as hardness, fossil content and porosity are variable which contributes towards their differences in terms of durability. For example, the Caen stone has two variants depending on its depositional fabric. The pelleted variety has high microporosity and is susceptible to weathering and the one dominated by bioclasts is less porous and less prone to 
alteration (Table 2). During formation, their durability is enhanced by cementation and recrystallisation that result in a reduction in total porosity. The degree of interlocking between component minerals is also an important textural attribute contributing towards the strength of a rock, with higher crystallinity resulting in higher strength. In general, geologically older carbonate rocks that have increased overburden pressure tend to have lower porosity and higher Young's modulus which makes them more durable, as evident for example, from the Carboniferous limestone such as Settle in Yorkshire, when compared to the younger Jurassic oolitic Bath Stone $[16,20]$. This can be understood in the context of the diagenetic alteration and changing character of the calcite cement in the primary pore spaces between original grains in a limestone as it progresses from sub-mature to mature. The cement growth initially starting as small crystals, finally recrystallises to form a denser fabric of fewer larger crystals, cutting across grain boundaries and resulting in a stronger fabric [21]. Any subsequent process of dolomitisation, when magnesium carbonate replaces the calcite or calcium carbonate, can enhance porosity with lowered unconfined compressive strength. Higher porosity also facilitates chemical weathering which leads to further enlargement of pore sizes, providing greater accessibility to oxygen, moisture and water with further chemical breakdown. A highly porous carbonate rock, with a significant fraction of pore diameter less than $2.5 \mu \mathrm{m}$, which facilitates capillary absorption of water and saturation of the stone, can be considerably damaged by freeze-thaw action [22]. When the internal surface area of the constituent grains is higher, they are more susceptible to water retention by adsorption and breakdown during weathering, as in the case of any pellets and ooids being present. On the contrary, the presence of crystalline shells can result in a lower internal surface area. For those building stones with lower microporosity, the clay fraction can be significant for its hygroscopicity and, by retarding the appearance of capillary bridges, reduces the rate of mechanical strength loss [23].

Carbonate rocks are strongly affected by dissolution in acidified water with disassociation to $\mathrm{Ca}^{2+} / \mathrm{Mg}^{2+}$ and $\mathrm{HCO}_{3}{ }^{-}$under rainwater $\mathrm{pH}$ of 4 to $7[24,25]$. The intensity of the rainfall is an important factor here with atmospheric pollution in urban areas accelerating the weathering rate. This has implications for anticipated increase in rainfall intensity related to climate change and air pollution for London. Even during the summer in which a seasonal decline of rainfall (Figure 1) is predicted, there can be later interaction and mobilisation during subsequent rainfall (or other forms of precipitation as well as humid air) of the accumulated dry deposits of sulphur dioxide, oxides of nitrogen, chlorides, sulphuric and nitric acids and particles such as soot, fly ash, etc., mostly emitted as combustion products of fossil fuels. When stones have a high specific surface area or a high deliquescent salt content, it can promote further dry deposition of $\mathrm{NO}_{x}$ [26]. This results in an enhanced acidity of the rainwater and pronounced carbonate dissolution from the building stones. As calcite dissolution is limited by the rainfall amount and its $\mathrm{pH}$, while sulphur dioxide in the atmosphere plays a major role in the damage of carbonate stone, other factors such as humidity and precipitation intensity are also important [24,25]. For example, the decay rate of Portland limestone shows a decline over time since the 1980s for both Munich and London (Figure 6), but this is not proportional to the reduction in atmospheric $\mathrm{SO}_{2}$ concentration during the same time period [27-29]. Additionally, the decay rate of Portland stone in London is considerably higher since the initial measurement period in the 1980s, as compared to Dublin or Munich (Figure 6), although the atmospheric $\mathrm{SO}_{2}$ concentration in 1978 is comparable $[28,29]$. As traditional air pollutants continue to decline, beside the effects of acid rain and dry deposition of gaseous pollutants, especially $\mathrm{SO}_{2}$ and $\mathrm{NO}_{x}$ discussed above, the degradation of carbonate stones by carbonate dissolution via the karst effect (with rain at $\mathrm{pH} \sim 5.6$ in equilibrium with atmospheric $\mathrm{CO}_{2}$ ) can be considerable. This is estimated to result in stone weathering of $\sim 18.8 \mu \mathrm{m} / \mathrm{m}$ at $330 \mathrm{ppm} \mathrm{CO}_{2}$ [30]. It can account for $\sim 96$ to $99.5 \%$ of the surface recession of carbonate stones from 1990 to 2099, arising not due to changes in rainfall but due to the predicted higher $\mathrm{CO}_{2}$ concentration of up to $750 \mathrm{ppm}$ [31]. Marbles are less prone to deterioration as compared to the limestones. Owing to their minimal porosity, they are not susceptible to the strong capillary suction that leads to rising damp, thereby limiting any salt damage [32]. 


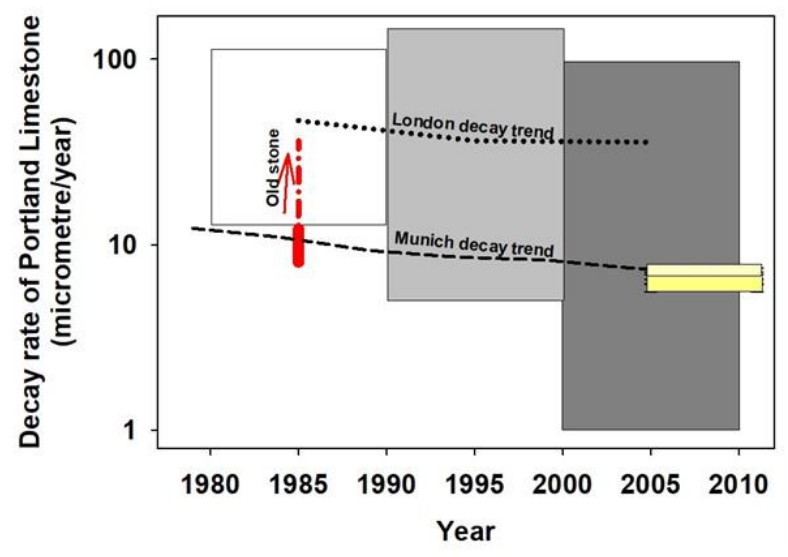

Figure 6. Decay rate of Portland stone in St. Paul's Cathedral, London, over three decades marked by boxes in white (1980-1990), light grey (1990-2000) and dark grey (2000-2010). The dotted line represents the trend indicating decline of the average decay rate. The decay rate for Mainz (dark yellow box) and Munich (light yellow box) and Trinity College Dublin (orange blob) are shown for comparison. The dashed line indicates the decline of the average decay rate for the stone in Munich. The orange arrow indicates an increase in decay rate for an old stone (relatively weathered rock) as compared to its new stone counterpart. Note that the decline in the trend of the decay rate for both London and Munich are not gentle in spite of the drastic reduction in the concentration of atmospheric $\mathrm{SO}_{2}$ over the same time period in both the cities. This indicates that other parameters are important in controlling Portland limestone deterioration. For further discussion, see text. Data sources: [27-29].

Subsequent to calcite dissolution, salts such as calcium and magnesium sulphates can crystallise at or near the surface, giving rise to efflorescence, or they can remain in solution and be transported by the moisture and rainwater trapped in carbonate rocks. This can result in a breakdown caused by crystallisation pressure, and hydration pressure if the salts recrystallise to different hydrates. Efflorescence often leads to exfoliation with losses of the outer layers of the rocks referred to as contour scaling. Crumpling by powder formation due to the crystallisation of soluble salts such as sodium chloride, sodium sulphate and sodium hydroxide, in addition to black crust formation by a mixture of gypsum and soot are also common deterioration features [16]. Differential thermal expansion can occur as the salts expand and contract at different rates from that of the host rocks during cycles of wetting and drying, and heating and cooling, resulting in the build-up of internal stresses. For example, halite can expand by $0.5 \%$ when the temperature increases from 0 to $60^{\circ} \mathrm{C}$. The gypsum formed can stabilise the surface and near surface stonework without any immediate impact on its interior when it maintains a good internal cohesion and adhesion to the underlying stone substrate [33,34]. Such crusts, having different levels of disintegration, can have different surficial manifestation of their morphology from laminar to framboidal [35]. Scaling and flaking of the crust can also be visible with formation of small blisters. When the major stress threshold is breached, there can be more rapid, catastrophic decay with multi layered flaking and large blister formation and, in severe instances crust detachment. Owing to its open crystalline structure, the black crust further accentuates moisture penetration bearing dissolved salts through the building stones.

In addition to crust formation, powder efflorescence can also occur, dominated by magnesium sulphate and only minor gypsum [33]. Due to the high solubility of magnesium sulphate, it only accumulates when water run-off is absent, which occurs in parts of structures that are sheltered. This also has implications for the predicted dry summer months in England where magnesian limestones are in use. Limestones are susceptible to soiling due to the accumulation of carbonaceous matter within the pore spaces, although soiling can be undone with cleaning [36]. Soiling can be locally concentrated, being determined by wind direction and protection from the rain, as well as the application of protective treatments that induce greater particle matter accumulation [37]. The process of limestone deterioration is summarised in Figure 7. 
Calcareous stones are prone to biodeterioration as they can be colonised by lithobiontic communities including bacteria, algae, fungi, lichen and mosses, sustained by the moisture retained in the pores on horizontal limestone surfaces as well as the inner zones that are pathways for moisture entrance and/or water accumulation [38,39]. Penetration of lichen hyphae within the substrate leads to physical destruction of the stone microfabric as well as chemical dissolution and corrosion of the underlying substrate affecting calcite grains in particular [39]. The latter occurs as "lichen substances", including organic acids such as oxalic acid, extract metallic cations from the stone to use as nutrients, leading to the formation of pits of up to $2 \mathrm{~cm}$ in diameter and depth [40]. This occurs with simultaneous precipitation of clusters of Ca-oxalate crystals, also found in the black crusts. In addition to gypsum, the black crust typically consists of calcite and quartz derived from the substrate, along with other non-carbonate carbon forms. With the relative increase in atmospheric nitrogen and organic compounds, with respect to $\mathrm{SO}_{2}$ leading to an increase in the biological activities and production of oxalates, formates and acetates in buildings such as the Tower of London, the yellowing may be of more concern than any darkening arising from the presence of elemental carbon [41].

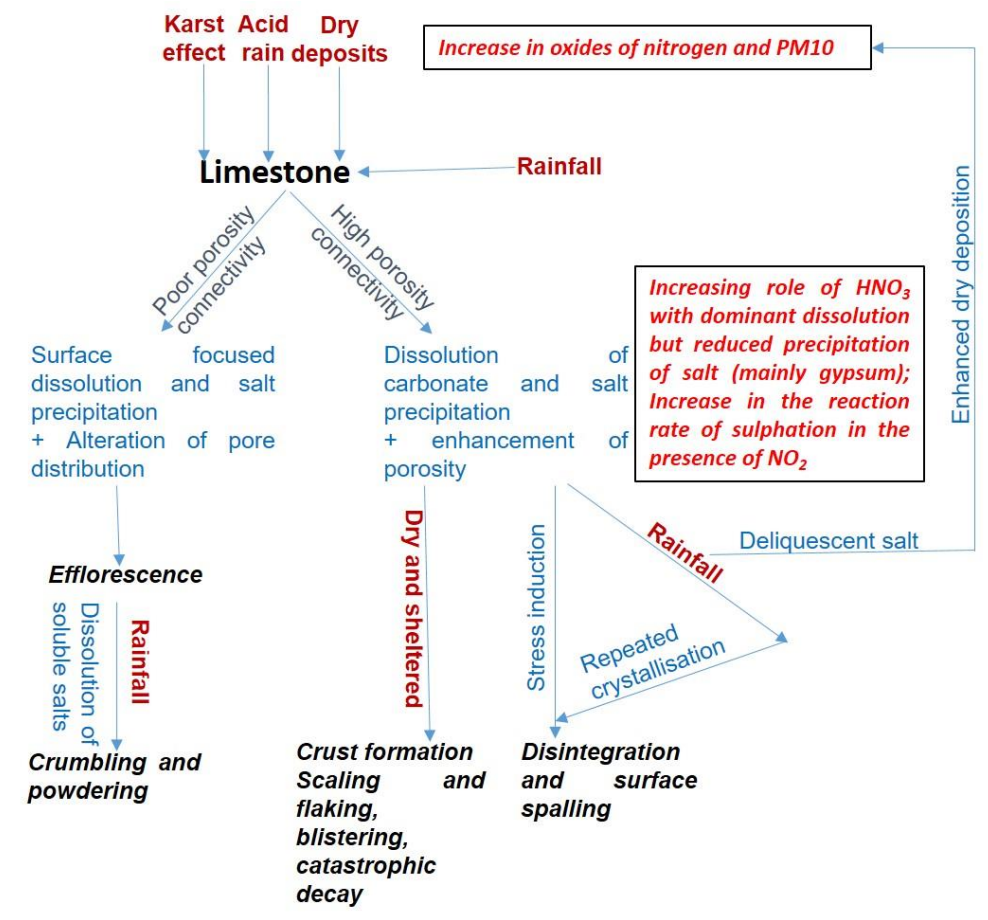

Figure 7. A model of limestone decay in urban settings, modified after [34,42]. Both rainfall and dryness may increase in the future as well as the concentration of atmospheric nitrogen oxides in London and other urban cities (indicated in red font in text boxes) which will affect decay processes (indicated in black font). In marble, microbial communities on stone surfaces are commonly observed. The surfaces can be cleaned by using suitable compounds although they can be subsequently recolonised [43]. Marble is also prone to efflorescence of salt such as sodium sulphate resulting in significant dissolution, with calcite being more susceptible than dolomite, reflected in a loss of gloss [44]. Degradation by microcracking is another major problem for marble, which is more pronounced during cooling than heating. This commences at a higher temperature differential for dolomitic marbles as dolomite has a lower thermal expansion anisotropy than calcite [45]. In addition, microcracking occurs at a larger temperature differential for decreased grain size and increased shape and lattice preferred orientation [45]. However, the effects of grain size and grain boundary were found to be insignificant for some marbles and made no difference even for polygonal grains with interlobate boundaries, but those with strong texture exhibited minimal residual strain following thermal treatment [45]. In the context of London and predicted temperature change, since cooling is expected to decline with time, any microcracking will be relatively limited. 


\subsection{Granite}

Granite is a crystalline rock that is commonly granular with a phaneritic texture. Occasionally, where the quartz, potash feldspar, plagioclase and biotite occur as mm-sized phenocrysts in a finer grained groundmass with interlocking mineral grains, it is referred to as the porphyritic texture. Resistance to any decay is higher when the biotite content is low along with a reduced capillary coefficient and anisotropy [46]. Granite is very often used in the facade of buildings (e.g., the British Library; see Figure 3), very close to a heavy traffic street and exposed to high levels of foot of traffic. Common forms of decay include spalling and granular disaggregation. Granular disaggregation occurs due to kaolinisation of feldspar and biotite, a weathering process that weakens the granitic microfabric due to the chemical and mineralogical transformation of feldspar (hardness $=6-6.5$ on the Mohs scale) to kaolinite (hardness $=2-2.5$ on the Mohs scale) $[47,48]$. The process is facilitated by wetting and drying cycles in moist and acid urban environments, accelerated by elevated $\mathrm{CO}_{2}$ and $\mathrm{SO}_{2}$ from anthropogenic activity. In a later stage of weathering, biotite can be replaced by chlorite along rims and lamellae under relatively oxidizing conditions, but the process of chloritisation can be of less significance in a generally acidic, urban environment. The spalling can be related to gypsum formation or aerosol deposition, as well as the use of gypsum and other lime-based mortars that can be a source of calcium [49]. This manifests as sulphate efflorescence resulting in decay as the salt crystallises on the surface or within pre-existing cracks or defects [44]. Sometimes, surficial staining is seen due to the salt formation of sulphates and nitrates by the use of cleaning products that were not neutralised [50]. Dark staining in granitic rock surfaces can be correlated with high moisture content, attributed to the formation of waterproof films by the application of water repellents during subsequent intervention [50]. While the decay of the feldspars chemically originated like the biotites and is mainly dependent on kaolinisation and chloritisation, the decay in quartz is dominantly mechanical and characterised as fissurisation under compression [51]. Quartz fissurisation is directly proportional to the mineral size while that of feldspar kaolinisation is inversely related.

In the weathering of granite, $\mathrm{SO}_{2}$ plays a dual role by promoting sulphate precipitation as well as kaolinisation of feldspar and biotite. Granite's reactivity with $\mathrm{SO}_{2}$ is low in general requiring hundreds of thousands of years to occur under natural conditions [52]. It has very low porosity (typical values for open porosity are 0.2 to $0.3 \%$ by volume, as compared to up to $30 \%$ for limestone). In urban areas, the sulphation reaction is due to availability of gaseous $\mathrm{SO}_{2}$ that can be adsorbed on the surface of the rock, as opposed to $\mathrm{SO}_{2}$ in aqueous or dissolved states in pore solutions [48]. It subsequently reacts with the calcium provided by the plagioclase sericitisation, accelerated in a $\mathrm{CO}_{2}+\mathrm{H}_{2} \mathrm{O}$ rich atmosphere [50]. This explains the occurrence of the weathering product of kaolinite at a depth of up to $4-5 \mathrm{~mm}$ from the granitic wall surface in northern Spain, coincident with a time of significant $\mathrm{SO}_{2}$ release [50]. Formation of an aeriform mixture of $\mathrm{SO}_{2}$ (gas) $+\mathrm{H}_{2} \mathrm{O}$ (vapour) can be more likely in the future in London as a rise in annual rainfall is predicted [5], although the availability of $\mathrm{SO}_{2}$ is anticipated to be lower. Alternatively, kaolinisation can occur if $\mathrm{CO}_{2}$ substitutes for $\mathrm{SO}_{2}$ in the reaction pathway of dissolution and chemical precipitation, but the rate of reaction is going to be slower [53].

Thermal stresses can lead to microcracking that accelerates decay and can be significant over a temperature range of 30 to $80^{\circ} \mathrm{C}$, with progressive coalescence of existing microcracks and generation of new ones [54]. This can lead to intracrystalline microcracking in K-feldspars and biotite along the direction of their cleavage planes or focused at the centre for the zoned plagioclase feldspars, while for the quartz, microcracking is intragranular with irregular patterns [55]. Over time, surface microcracking will lead to crystal disintegration and detachment as well as facade scaling and flaking [55]. The microcracks also accelerate biodeterioration by biological colonisation by lichen and plants. This leads to disaggregation of the stone fabric as any penetrating lichen hyphae enhances pre-existing points of weakness, such as cleavage planes in feldspar and mica, as well as intragranular cracks in quartz grains [50]. The physical disintegration is accompanied by chemical decay. This is manifested as etching pits and dissolution cavities in feldspar and mica, as well as the chemically resistant quartz and apatite, often accompanied by the precipitation of amorphous deposits, 
suggesting that the biological patina often derives its constituents from the disaggregated granitic surface [50]. As the feldspars, both plagioclase and potash feldspar, undergo microcracking due to physical weathering processes such as freeze-thaw, it results in crystal loss and facilitates chemical alteration processes by providing access pathways to fluid flow and air pollutants [48]. This is in agreement with observations of the higher rate of chemical weathering for plagioclase than K-feldspar, that can be related to the increased rate of physical weathering for plagioclase driven by different mechanisms of microcracking related to their microstructures and crystallographic anisotropies. Zoned, plagioclase crystals with a high number of core microcracks are susceptible to seritisation at the core where there is also more calcium than in the perimeter zone, driven by a combination of deuteric alteration and physical disintegration. However, under predicted climate change for London, due to relatively wetter but warmer winter conditions [5], freeze-thaw processes may be greatly reduced in the future. Sometimes a heterogeneity in relief can be observed for granitic surfaces with darker, microgranular enclaves appearing to be more weathered than the surroundings. This phenomenon is poorly understood but can be related to the lower albedo of the darker enclaves enriched in biotite and plagioclase, as compared to the remaining rock. This promotes differential spalling with only a thin detachment of the stone where the decay is accelerated by the lower conductivity and the heat capacity leading to overheating of the enclaves [52]. The processes of deterioration of a granite is summarised in Figure 8.

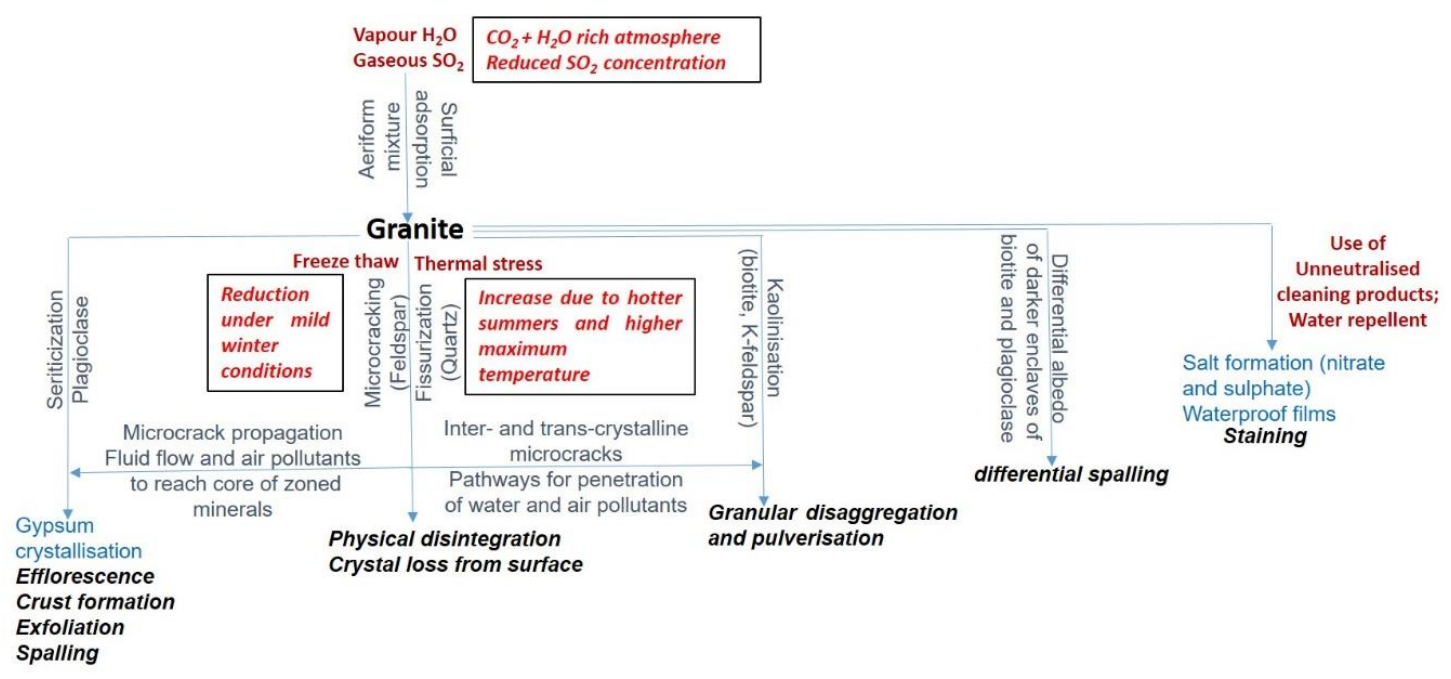

Figure 8. Model of granite decay in an urban setting. Since the concentration of atmospheric sulphur dioxide in London and other urban cities is expected to continue to decrease, the frequency of many decay processes for granite such as kaolinisation and gypsum crystallisation are also likely to be decrease.

\subsection{Sandstone}

Sandstones are variable in mineralogy depending on their provenance which determines the original deposited clastic material and diagenesis, and in turn controls their subsequent evolution by compaction and cementation. The diagenetic evolution finally determines its effective porosity, along with its pore space distribution, the pore geometries and their interconnections. The major decay process, affecting any sandstone, is salt weathering with the pore spaces being a major determinant as it is where the crystallisation processes take place [56]. Water transport and storage are key factors associated with pore space and sizes. A larger interconnected pore network that can facilitate moisture saturation is often related to a higher rate of salt crystallisation but cannot be solely attributed to it. While crystal growth can occur preferably in the larger pores, the residual solution as well as any absorbed moisture in the smaller pores represents a reservoir for possible subsequent crystal growth in the larger pores [57]. Consequently, the sandstones with a bimodal pore-size distribution or, with a 
sub-maximum in the smaller pore ranges are more sensitive to salt weathering [58]. For any sandstone with an equal pore radii distribution, a capillary water uptake will occur, though constrained mainly to the driving rain season [59], with some contribution from moisture rising from the foundations or lower wall elevations. The uptake of water and its transportation occurs dominantly across the pores ranging in size from 0.01 to $1000 \mu \mathrm{m}$ in radii which is most likely to control the effective porosity of the sandstone [59]. Any secondary porosity can be subsequently generated if the water invades the matrix [59]. Because of the porous nature of sandstones, there is likely to be constant accumulation of salts at the point of evaporation from aqueous salt solutions, where the generated crystallisation pressures can lead to degradation. In addition to the repeated dissolution-crystallisation cycles of the salts in the porous network, the pore walls can be subjected to destructive hydration pressures, induced by salts as they undergo a phase transition during wetting. Osmotic swelling of clays, differential thermal expansion and wet/dry cycles by deliquescent salt are other mechanisms of salt weathering [32].

The availability of moisture is regulated by rainfall, capillary rising damp or condensation. Depending on the relative humidity, there might be moisture stains affecting the appearance of stone when there is deliquescence or, salt crystallisation with pressure exertion and material damage if there is evaporation. Beside rainfall and relative humidity, the other important factor is the temperature that controls the evaporation rate and consequently, the degree of supersaturation of the salt and the resulting damage. The type, amount and distribution of the salt present also regulates the intensity of salt weathering. In urban areas, gaseous pollutants may react with the porous building material forming different types of salts including the nitrates, sulphates and the carbonates [60]. The salts present are a complex mixture of ions which have significant implications. For example, when the most common salts, halite and gypsum, coexist in the presence of sodium chloride, the solubility of gypsum increases which aids its migration and recrystallisation [61]. For a mixture of salts, the highest salt content may not imply the greatest damage, as ion mixtures that are strongly hygroscopic will not crystallise under normal conditions [32]. Furthermore, the damage may not be proportional to the component salts, with certain salt mixtures causing more intensified weathering [32].

The porosity and the pore size distribution, important for regulating the moisture content and its accumulation with implications for water absorption, salt loading and hygric dilatation, can be ultimately related to the lithology [62]. For example, a decrease in hygric dilatation and an increase in salt resistance is observed with increasing compositional and textural maturity from litharenites to quartz arenites as the pore distribution changes from bimodal, to unimodal unequal to unimodal equal. For a quartz arenite with a unimodal equal pore-radii distribution, it is characterised by restricted moisture absorption and, in spite of a quick capillary water uptake during driving rain, it has low water retention due to its missing smaller capillaries and a high drying velocity [59]. However, its pore sizes can be significantly reduced during diagenetic cementation. On the other hand, the presence of additional smaller pores (as in a sublitharenite) is characterised by a higher water content as the additional smaller pores allow the absorption of moisture via sorption.

The transportation of the salt is controlled by ion diffusion, which requires continued saturation but is also determined by pore connectivity, mineralogy and sedimentary structures [63]. Ion diffusion leads to the distribution of salt throughout the rock mass as penetrating saline solution that, keeps the sandstone blocks saturated for an extended period of time and facilitates chemical reaction with the mineral constituents present [63]. To maintain continued saturation, there should be consecutive wet days to maintain wetness. However, even if the surface/near-surface zone dries out by evaporation, there can still be a significant reservoir of moisture at depth, driving chemical action in the stone interior [63]. The connectivity of pores allows the ions to move through the stone along the concentration gradient, but can be modified as weathering proceeds, where salt solutions reach their saturation and may crystallise out of solution, blocking pore throats.

The mineralogy also impacts porosity and adsorption capacity. For example, any mica present can disaggregate and accumulate in the pore spaces, thereby reducing the porosity and simultaneously increasing the surface area available for the adsorption of hydrated ions that lowers the overall 
diffusion [63]. Like the clay minerals, the micas can also "fix" ions in the interlamellar spaces of their structure that decrease the overall diffusion process. Other factors that need to be considered are physical heterogeneities such as the presence of clay layers that influence moisture regimes [59]. The presence of clay layers within a sandstone, induces additional stress due to their high sorption capacity and diffusion resistance and promotes a retarded interaction with the environment by acting as a barrier to water migration. Mixed layers of clays such as chlorite and smectite may undergo intracrystalline swelling in the presence of water, while chlorite-illite may be subjected to osmotic swelling processes facilitated by the presence of sodium chloride in the pore spaces inducing a concentration gradient of $\mathrm{Na}$ ions between the clay particles and rock pores [64]. The presence of bedding layers inhibits the rate of diffusion if they are perpendicular to the concentration gradient, although if the diffusion gradient is bedding parallel, it is possible that the rate of diffusion can be accelerated [58]. Hydric swelling of clay minerals is pronounced when their basal planes act as planes of weaknesses with orientation parallel to the original sedimentation beds [64].

Salt weathering in a sandstone, controlled by fluctuations in temperature and moisture, occurs when there is frequent wetting and drying in the near-surface zone. This causes repeated crystallisation of salt with complex three-dimensional distribution in the rock mass, that undergo repeated hydration/dehydration and expansion/contraction [63]. It leads to efflorescence and finally, in surface losses in the form of granular disaggregation, scaling and multiple flaking [63]. Although stone surfaces may appear stable for a considerable period of time, the stress caused by accumulated salts can eventually exceed the threshold of stone strength and trigger material loss [65]. The penetrating saline solution can lead to selective silica dissolution thereby weakening the stone matrix and/or the grain boundary cementing. Biodeterioration of sandstone occurs as a result of the dissolution of the constituent silicates and nitrates and particularly the carbonates that often weaken the stone cement, this is due to the action of carbonic acid formed when the surface water reacts with the produced carbon dioxide from microbial respiration [66]. Under increased moisture conditions, with a relative humidity of 80 to $>90 \%$, fungal infestation can be particularly enhanced-especially when the porosity is high, and the pores are interconnected. The fungi further proliferate in the presence of black crust and also activate formation of new biominerals [67]. The prevalent deterioration processes of sandstone are summarised in Figure 9.

In London, considering the effect of climate change (Figure 1) with predicted wetter winter months and higher annual precipitation, ion diffusion may become more pronounced as a mechanism of salt transportation and the salts are likely to stay in solution longer [63]. While this will delay the onset of crystallisation of the salts on one hand, on the other hand it may considerably weaken the rock cement by extending further the depth of the wetting front and increasing further the mobilisation and precipitation of the constituent elements of the rock mass. Consequently, when the salt eventually crystallises out of the solution, the rock will be too damaged to withstand any stress and may damage more easily. The decay initiated at the surface, will vary with depth of the material, with some time delay before the onset of decay at the deeper portions of the building material [60]. Biodeterioration can be more pronounced for the mesophilic fungi that flourish under temperature of $20-45^{\circ} \mathrm{C}$ under enhanced relative humidity in the future. The biogeochemical effects of organisms can promote salt attack by increasing the moisture content and pore volume while precipitating sulphates and oxalates [68]. On the other hand, it can decrease salt weathering by reducing the effective permeability, preventing pollutant accumulation and altering thermal characteristics and wetting times of stone. With predicted greater seasonal variability in rainfall and consequent relative humidity, the swelling and shrinkage of different clay phases can have different impacts on the mechanical and fracture behaviour of the building stones. High swelling clay phases such as smectite and glauconite can have great influence on the stone properties, even with low moisture content during the summer, while the less swelling chlorite and interlayers of chlorite-smectite can impact only when the moisture content is higher during the winter months [69]. 


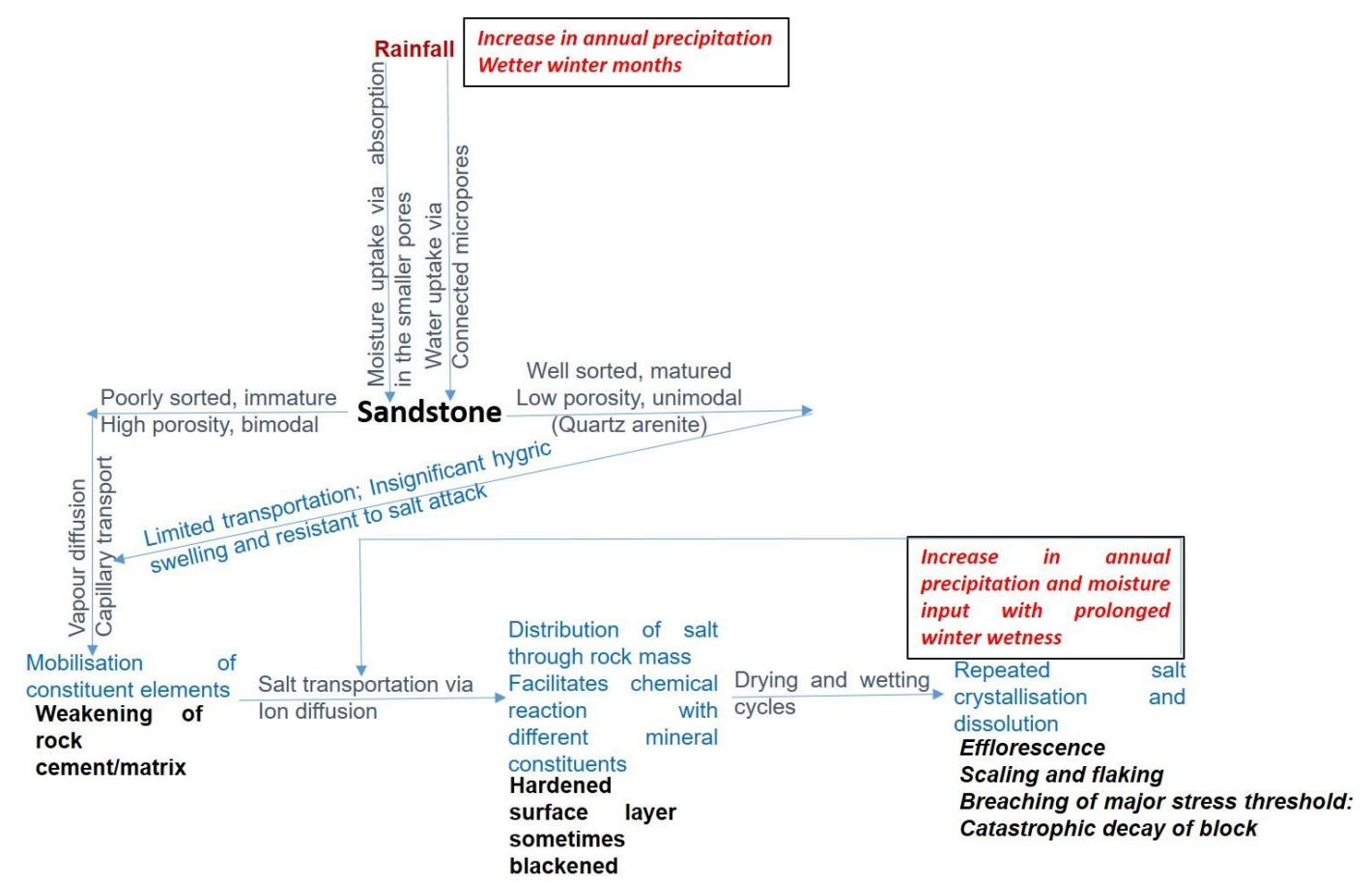

Figure 9. A model of sandstone decay in an urban setting, modified after [34]; predicted overall increase in annual rainfall and prolonged wetter winters for London in the future (indicated in red font in text boxes) can affect corresponding decay processes such as the onset of salt crystallisation and period of wetting.

\subsection{Flint}

Flint is a compact crystalline silica, black or dark blue-grey in colour with a trace element contamination. The microcrystalline silica can occur as nodules or bands, closely associated with chalk, with calcium carbonate often forming a coating of white cortex around the core in a nodule. They are concretions, formed during the natural growth of precipitated mineral matter around a core. A complex process converts the fine particles to nodules or cobbles of various sizes, as a result of chemical changes in the compressed sedimentary rock formation as it undergoes diagenesis.

The tough, intractable, siliceous nature of flint is the source of its great durability. This durability is restricted to individual units making it difficult to split and shape, and it does not necessarily upscale to masonry walls made with flint [70]. While the intrinsic morphological characteristics of masonry may induce additional decay and failure mechanisms into masonry walls, it is of particular concern for those made of flint units. This is because it is especially difficult to construct a vertical wall using flint in its rough, nodular, field form without resorting to the use of very large quantities of mortar to set the irregular flints, making the behaviour and integrity of the final product, both structurally and under environmental exposure, heavily dependent on mortar (see Section 2.6). For the proper bonding of the flint face to its backing, it is very important that the flint is well anchored in hydraulic lime mortar or supported by stainless steel wire ties or anchors. The backing or core, often built of compacted brick and flint, also need to be well built and consolidated.

While any impact of climate change for the flint itself used in London is likely to be minimum, caution should be executed when selecting the mortar for binding them. Cement mortar if used, can be susceptible to changing thermal conditions and moisture availability.

\subsection{Slates}

The term slate defines a fine-grained metamorphic rock that underwent low-grade regional metamorphism and possesses slaty cleavage due to the alignment of phyllosilicate minerals, mainly 
mica and chlorite [71]. Compositionally, the main minerals present are quartz, mica and chlorite with varying quantities of accessories including rutile, zircon, monazite, tourmaline and organic matter, in addition to secondary minerals such as iron sulphides and carbonates. Colour of slates are variable, reflecting variation in mineral content and chemistry, but generally range between light and dark grey. It is commonly used as roof cladding as it can be split into plane, thin and regular tiles. The UK has a long tradition of slate mining with some remaining quarries still providing slate for restoration of architectural heritage and special buildings.

Slate can be degraded by salt attack or freeze-thaw impacts, as well as thermal and hydric variations. However, compared to other building stones, roofing slate is less prone to develop alteration due to the low chemical reactivity of the main constituent minerals, the quartz and the phyllosilicates. Iron sulphides such as pyrite and pyrrhotite, as well as the carbonates can be the most damaging group of minerals in terms of the integrity of any slate [72,73]. For example, a slate containing coarse-grained pyrite as inclusions, is not very stable against temperature changes, due to the difference in thermal expansion among the rock constituents [74]. Iron sulphide oxidation also produces red staining that affects the tile surface and the other tiles below. Particularly, any macro sulphide inclusions, visible with naked eye, are a potential source of oxidation. There can also be some discolouration due to gypsification, when carbonates are converted to gypsum, triggered in the presence of water in an acidic environment. Since gypsum has a higher volume than carbonate, its growth in the slate matrix results in disintegration of the slate [75]. The flexural strength of the slate is anisotropic due to its slaty cleavage, with generally a high-water uptake associated with low flexural strength.

For predicted climate change in London, little impact on slate is predicted but some caution is advocated. For example, with increasing rainfall, in the presence of water along with oxygen, any pyrite present can be oxidised to ferrous and ferric sulphates and sulphuric acid. With the consequent drop in $\mathrm{pH}$ value, it can lead to further dissolution of any other metal salts present. The possibility of the phyllosilicates present undergoing alteration and transformation cannot also be entirely ruled out as they are more sensitive to heat than quartz. However, for those slates selected on the basis of their intrinsic properties, providing they have no impurities, they can be very resistant as building stones.

\subsection{Lime Mortar}

In early times, the mortars were a mixture of lime, ash and brick aggregate and reactive volcanic ash (true pozzolana) [70]. Where true pozzolana was not available it was substituted by ceramic pozzolans. The bricks were fired at low temperatures and crushed to a fine particle size that reacted with some of the lime to form calcium aluminates and silicates, imparting a hydraulic set to the mortar. This mixture of mortar had a permeability that allowed water to evaporate through the pore structures, while also providing sufficient adhesion and flexural strength to enable minor structural movements in the masonry without cracking. Later builders used lime mortars without ceramic powder but still containing significant quantities of kiln residues which could also impart a weak hydraulic set. Alternatively, they used natural hydraulic limes with the addition of tallow or beeswax. The use of traditional compatible mortars in retrofit and conservation maintenance is crucial to ensure physical, chemical and structural compatibility with the original fabric. However, due to a long period of use of cementitious mortars incompatible with traditional materials in many heritage sites, more pronounced shrinkage cracks develop continuously through the mortar to accommodate movement caused by thermal and moisture changes. Cement rich mortar also inhibits the free evaporation of moisture which enters through cracks and contributes to the overall dampness of the wall and can result in mechanical failure due to frost formation. If detachment and major cracking occurs, the area affected has be dismantled and rebuilt. Lime putty for sheltered exposures (sand, porous limestone and brick pozzolan) and hydraulic lime for moderate to severe exposures (sand and porous limestone) can be effective as mortar and, should be placed by ensuring thorough compaction and filling of irregular voids. 
Limestone and marble, both calcitic and dolomitic, are commonly used for quick lime production. Like the parent rocks, lime mortar is also affected by higher levels of $\mathrm{CO}_{2}$ and intense acid rainfall. Sulphation of dolomitic lime mortars can lead to the formation of magnesium sulphate and gypsum due to preferential dissolution during exposure to rain [75]. The less soluble gypsum remains confined in the mortar structure, but the more soluble magnesium sulphate can be washed out by rain, and preferentially efflorescence in the outermost layer of the material accumulates in the rain sheltered part of the facade in the porous building stones and bricks causing major deterioration. In general, for repair mortars, depending on their binder/aggregate ratios, the strength decreases while porosity increases with increasing aggregate content [76]. It is yet to be determined whether such lime mortar can be effectively used in an acidic urban environment such as that predicted for London, which would be exacerbated by increasing rainfall.

\subsection{Bricks}

Bricks are silicate-based, commonly made of firmly cast clay that is not directly affected by acidic rainwater. The best quality clays, as used in the British Library, are high in pure alumina and without any gypsum [17]. They are fired in a kiln at high temperature with controlled oxygen concentrations creating the conditions to produce the red colour. During the process, when the gas escape, it creates small cavities at the surface. For any lime mortar used, the calcium carbonate binder can be dissolved away when it reacts with the acidic rainwater producing soluble salts such as gypsum which are transported in solution in the pore spaces and cavities of both the bricks and the mortar [77]. When the water evaporates and soluble salts are finally deposited, they accumulate over time within the pores forming a thin outer layer or skin with different moisture and thermal movement compared to the substrate. This induces stresses between the skin and the substrate, leading to superficial detachment and blistering. For bricks, their joints with mortar often occur as points of weaknesses [78]. They are prone to damage by salt weathering but the moisture penetration is limited by depth and height as it is distributed by capillary action, which also implies that while the more soluble salts, such as the chlorides and nitrates, can penetrate to greater depth and height, the sulphates are relatively restricted to the surfaces [78]. Different types of bricks can still continue to be used in London but only with appropriate mortar as a binder, that are not susceptible to reaction with acidic rainwater.

Table 2. Details of some varieties of limestone, sandstone and granite commonly used in London building stones, with their description and distinguishing properties that govern their durability and purpose of use in the site and possible deterioration over time. Depending on their intrinsic properties related to their heterogeneous fabric, their deterioration exacerbated by climate change will be different.

\begin{tabular}{|c|c|c|c|c|}
\hline Building Stone & $\begin{array}{l}\text { Provenance and } \\
\text { Age of Formation }\end{array}$ & Description & $\begin{array}{c}\text { Distinguishing Properties Related } \\
\text { to Usage }\end{array}$ & $\begin{array}{c}\text { Deterioration that can be } \\
\text { Exacerbated by * Climate } \\
\text { Change }\end{array}$ \\
\hline \multicolumn{5}{|c|}{ Limestone } \\
\hline Portland stone [21] & $\begin{array}{c}\text { Dorset (UK) } \\
\text { Upper Jurassic } \\
\text { (152 to } 145 \mathrm{Ma})\end{array}$ & $\begin{array}{l}\text { Formed of "oolites" } \\
\text { cemented by calcitic cement. } \\
\text { The oolites are formed when } \\
\text { tiny sand grains act as nuclei } \\
\text { for deposition of concentric } \\
\text { layers of carbonate material } \\
\text { around it, physically evenly } \\
\text { rounded by the action of } \\
\text { waves and water currents. } \\
\text { Some calcareous algal pellets } \\
\text { as well as shell fragments } \\
\text { can be present. }\end{array}$ & $\begin{array}{l}\text { The well-cemented nature of Portland } \\
\text { Stone contributes to the compactness } \\
\text { and strength. The oolites behave like } \\
\text { well-distributed ball bearings, and } \\
\text { consequently the rocks lack any } \\
\text { directional properties and can be cut } \\
\text { with equal ease in all directions. } \\
\text { The microporous oolites that often } \\
\text { bear traces of borings are infilled by } \\
\text { diagenetic calcitic cement, thereby } \\
\text { reducing the microporosity and } \\
\text { adding further strength. Large } \\
\text { volumes of primary pore spaces } \\
\text { remain uncemented. These } \\
\text { interconnected, intergranular } \\
\text { macropores offer pathways for drying } \\
\text { out after wetting, making the stones } \\
\text { more resistant to the impact of cyclic } \\
\text { wetting and drying. }\end{array}$ & $\begin{array}{l}\text { Generally resistant, but once } \\
\text { already weathered, } \\
\text { the added pore spaces can } \\
\text { provide increased surface } \\
\text { area for dissolution and, } \\
\text { water and moisture } \\
\text { retention. }\end{array}$ \\
\hline
\end{tabular}


Table 2. Cont.

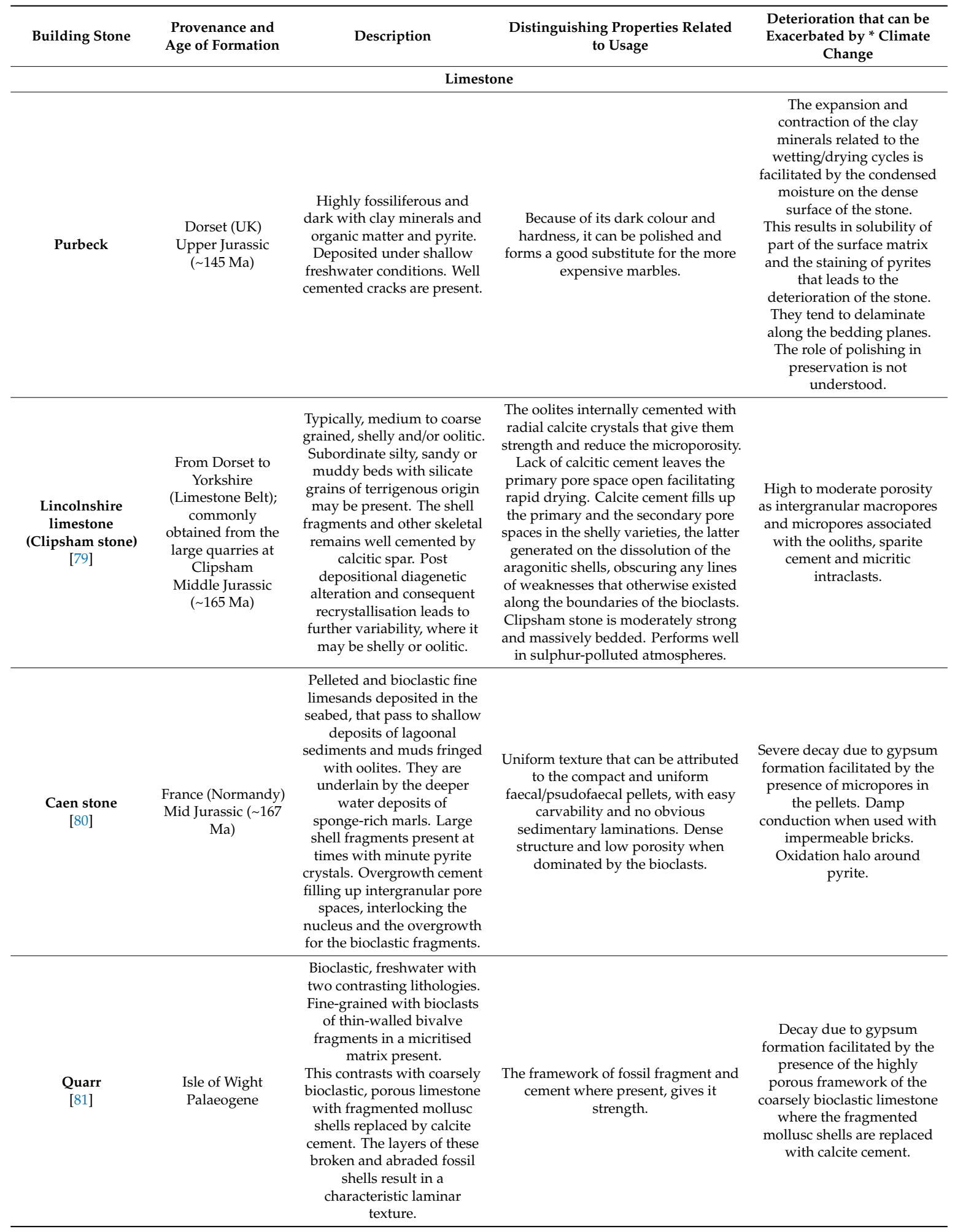


Table 2. Cont

\begin{tabular}{|c|c|c|c|c|}
\hline Building Stone & $\begin{array}{l}\text { Provenance and } \\
\text { Age of Formation }\end{array}$ & Description & $\begin{array}{c}\text { Distinguishing Properties Related } \\
\text { to Usage }\end{array}$ & $\begin{array}{l}\text { Deterioration that can be } \\
\text { Exacerbated by * Climate } \\
\text { Change }\end{array}$ \\
\hline \multicolumn{5}{|c|}{ Limestone } \\
\hline $\begin{array}{c}\text { Magnesian } \\
\text { limestone } \\
{[82,83]}\end{array}$ & $\begin{array}{c}\text { Quarries at } \\
\text { Bolsover Moor } \\
\text { (Derbyshire, } \\
\text { Mansfield } \\
\text { (Nottinghamshire) } \\
\text { and Anston (South } \\
\text { Yorkshire) }\end{array}$ & $\begin{array}{l}\text { Diagenetically altered-the } \\
\text { original bioclastic fabric } \\
\text { remains intact when the } \\
\text { alteration is minimal } \\
\text { otherwise a coarse } \\
\text { crystalline fabric develops } \\
\text { with no relict of its primary } \\
\text { depositional structure or } \\
\text { fabric. }\end{array}$ & $\begin{array}{l}\text { An interlocking, porous framework } \\
\text { with a high proportion of fine sand } \\
\text { quartz grains. The crystalline texture } \\
\text { along with the highly resistant quartz } \\
\text { grains contributes to the durability. } \\
\text { The common occurrence of large open } \\
\text { or carbonate crystal-lined cavities or } \\
\text { vugs as a consequence of } \\
\text { recrystallisation, can favour drying. }\end{array}$ & $\begin{array}{l}\text { In urban settings, } \\
\text { magnesium salts are more } \\
\text { soluble than calcium rich } \\
\text { varieties. Once affected by } \\
\text { acid rain, the derived } \\
\text { magnesium sulphate } \\
\text { by-products within the pore } \\
\text { spaces have a greater } \\
\text { volumetric expansion as } \\
\text { compared to gypsum. } \\
\text { For the Anston stones, } \\
\text { the original bioclastic texture } \\
\text { has been preserved despite } \\
\text { the olomitization, with the } \\
\text { framework consisting of } \\
\text { accumulations of abraded, } \\
\text { dolomitised, bioclastic } \\
\text { fragments. This bioclastic } \\
\text { framework with the } \\
\text { interconnected pore network } \\
\text { compromises the durability } \\
\text { of the stones. } \\
\text { Affected by surface } \\
\text { discoloration, efflorescence, } \\
\text { blistering and ultimately } \\
\text { severe surface exfoliation. }\end{array}$ \\
\hline $\begin{array}{c}\text { Kentish ragstone } \\
\text { (Lower Greensand } \\
\text { Bed) } \\
{[19]}\end{array}$ & $\begin{array}{c}\text { Kent } \\
(\sim 115 \text { to } 110 \mathrm{Ma})\end{array}$ & $\begin{array}{l}\text { Grey in colour, consisting of } \\
\text { rounded detrital grains of } \\
\text { quartz and the green iron } \\
\text { silicate mineral glauconite, } \\
\text { with associated bioclasts, } \\
\text { cemented by diagenetic } \\
\text { calcite. }\end{array}$ & $\begin{array}{l}\text { Hard due to cementing that } \\
\text { contributes to the overall strength. }\end{array}$ & $\begin{array}{l}\text { Numerous fractures, } \\
\text { identified under optical } \\
\text { microscope, distributed } \\
\text { throughout the rock } \\
\text { contribute towards a high } \\
\text { secondary porosity that } \\
\text { weakens the rock structure. } \\
\text { An inhomogeneous texture } \\
\text { and high microporosity that } \\
\text { can be attributed to } \\
\text { diagenetic recrystallisation } \\
\text { contributes to the } \\
\text { degradation of the stone. }\end{array}$ \\
\hline \multicolumn{5}{|c|}{ Sandstone } \\
\hline $\begin{array}{c}\text { Reigate stone } \\
\text { (Upper Greensand } \\
\text { Bed) } \\
{[84]}\end{array}$ & $\begin{array}{c}\text { Surrey } \\
\text { Lower Cretaceous } \\
(105 \mathrm{Ma})\end{array}$ & $\begin{array}{l}\text { Calcareous sandstone/sandy } \\
\text { limestone. } \\
\text { Sandy and glauconitic, well } \\
\text { cemented with silica and } \\
\text { calcite cement. Bioturbation } \\
\text { features are common. Beside } \\
\text { glauconite, bioclastic debris } \\
\text { also comprises the } \\
\text { framework, with dominant } \\
\text { fine to medium grained } \\
\text { quartz. }\end{array}$ & $\begin{array}{l}\text { Variation in the proportion of quartz } \\
\text { grains, glauconite and carbonate } \\
\text { cement/matrix. Though, if } \\
\text { well-cemented, it can be highly } \\
\text { durable and requires low } \\
\text { maintenance over its life [85]. } \\
\text { Additionally, it has a high thermal } \\
\text { expansion capacity. }\end{array}$ & $\begin{array}{c}\text { Often soft and weakly } \\
\text { compacted and porous, and } \\
\text { therefore swells when wet. } \\
\text { Exhibits pronounced } \\
\text { contour scaling and flaking } \\
\text { when exposed (Figure 5) and } \\
\text { surface powdering in } \\
\text { sheltered areas. }\end{array}$ \\
\hline
\end{tabular}


Table 2. Cont.

\begin{tabular}{|c|c|c|c|c|}
\hline Building Stone & $\begin{array}{l}\text { Provenance and } \\
\text { Age of Formation }\end{array}$ & Description & $\begin{array}{c}\text { Distinguishing Properties Related } \\
\text { to Usage }\end{array}$ & $\begin{array}{c}\text { Deterioration that can be } \\
\text { Exacerbated by * Climate } \\
\text { Change }\end{array}$ \\
\hline \multicolumn{5}{|c|}{ Granite } \\
\hline $\begin{array}{l}\text { Aberdeen } \\
\text { Scottish } \\
\text { Cornish: } \\
\text { (Dartmoor, } \\
\text { Bodmin Moor } \\
\text { (Cheesewring); } \\
\text { Cumbria } \\
\text { Shap Granite }\end{array}$ & Variable & $\begin{array}{l}\text { Many varieties. } \\
\text { Coarsely crystalline with } \\
\text { quartz, feldspar and biotite } \\
\text { mica with various accessory } \\
\text { minerals. Large phenocrysts } \\
\text { of K-feldspar may be set in } \\
\text { the groundmass (porphyritic } \\
\text { texture) but in some cases } \\
\text { may be relatively finer } \\
\text { grained. }\end{array}$ & $\begin{array}{l}\text { The interlocking crystals provide } \\
\text { cohesion which adds strength and } \\
\text { makes them suitable for polishing } \\
\text { without plucking of the grains. } \\
\text { The predominance of silica and other } \\
\text { relatively stable minerals make it } \\
\text { particularly strong and durable. }\end{array}$ & $\begin{array}{l}\text { Incipient kaolinisation } \\
\text { causing the feldspars to } \\
\text { become cloudy; } \\
\text { deferruginisation resulting } \\
\text { in the release of iron from } \\
\text { the biotite and its dispersal } \\
\text { throughout the rock body, } \\
\text { thereby discolouring the } \\
\text { rock to some rusty shade } \\
\text { due to iron oxide staining. } \\
\text { Water leakage through joints } \\
\text { when of inferior quality } \\
\text { comprising smaller block } \\
\text { size. Smearing by white lime } \\
\text { from the mortar between } \\
\text { such blocks. }\end{array}$ \\
\hline Royken & (Norway, 250 Ma) & $\begin{array}{l}\text { An interlocking texture of } \\
\text { prominent coarse, feldspar } \\
\text { laths seen, set against a } \\
\text { background groundmass of } \\
\text { finer grey-to-dark-grey } \\
\text { quartz, with flakes of black } \\
\text { biotite mica with some } \\
\text { silvery muscovite mica also } \\
\text { present Figure 3C. Textures } \\
\text { show some contrasts, with } \\
\text { variable size of the feldspar } \\
\text { laths from very coarse to } \\
\text { slender. }\end{array}$ & $\begin{array}{l}\text { The crystalline texture of the rock } \\
\text { with the interlocking mineral grains } \\
\text { give it compactness and strength. } \\
\text { The reddish colour of the rock can be } \\
\text { attributed to the presence of } \\
\text { potassium feldspar that adds to the } \\
\text { aesthetic. The granite surface is } \\
\text { roughened underfoot by the tougher } \\
\text { crystals of feldspar, a perfect non-slip } \\
\text { surface on a wet day. }\end{array}$ & As above \\
\hline
\end{tabular}

* In London, a temperature rise of $3-8{ }^{\circ} \mathrm{C}$ during the summer with a precipitation drop by up to $10 \%$, and a winter precipitation increase of up to $60 \%$ is predicted by 2080-2099 from a 1981-2000 baseline [5].

\section{Deterioration of Building Stones in London: Future Directions of Study}

From the previous discussion, it is clear that the building stones in large urban areas such as London are likely to be largely affected by increasing atmospheric pollution compounded with change in rainfall intensity and urban temperatures. The $\mathrm{SO}_{2}$ concentrations have a strong influence on stone deterioration but its concentration in London has decreased by four times from $220 \mu \mathrm{g} / \mathrm{m}^{3}$ since the period 1960 to 1980 [86]. The decay rate of Portland limestone, a common building stone in London, measured in St Paul's Cathedral in London is $220 \mu \mathrm{m} /$ year based on the runoff analysis of the calcium ions being added, however, it is lower at $130 \mu \mathrm{m} /$ year based on the direct measurement of erosion [16]. This can be attributed to differences in the relative contribution of solution and particulate losses to the total loss that is strongly controlled by porosity, often enhanced in weathered samples [27]. Higher porosity offers more surface area for chemical dissolution and increased retention of water further facilitating solution. A decay rate of 35-49 $\mu \mathrm{m} /$ year for the same site in London, over 30 years assessed as surface lowering [28], is still higher compared to the same building rock in other cities such as Dublin and Munich (Figure 2). However, in Munich the assessment was based on available dose-response functions for Portland limestone, pre-derived from exposure experiments at different locations with different climate and pollutant concentrations [29]. In Dublin, the assessment was based on runoff analyses of exposed micro-catchment units, for both freshly quarried and relatively weathered rocks [27]. Beside the surficial runoff, it is very important to consider that the dissolved decay products may be re-precipitated within the pore spaces of the building stones. For all practical purposes, a comparison between different studies may not be always straightforward until an equivalent methodology is used, or diverse methods can be universally calibrated.

It is important to consider that a rise in the level of the oxides of nitrogen acts as catalyst for the formation of sulphates, the concentrations of which have increased two-fold in London over the last fifty years [86]. Consequently, current $\mathrm{SO}_{2}$ concentrations can still affect stone deterioration, especially in the context of increasing particulate matter. $\mathrm{NO}_{2}$ can function as an oxidant and significantly 
increase the reaction rates of the sulfation processes. In addition, $\mathrm{NO}_{x}$ gases can be oxidised by lithotrophic bacteria to nitric acid, which contributes towards stone decay [87]. The annual recession rate of Portland limestone in Munich has dropped down from approximately 12 to $7 \mu \mathrm{m}$ between 1979 and 2009 (Figure 2), accompanied by a decrease in $\mathrm{SO}_{2}$ but with an increasing influence of acidity from $\mathrm{HNO}_{3}$ as a consequence of higher $\mathrm{NO}_{2}$ from emitted combustion gases, along with rising PM10 particulates [37]. This influence of $\mathrm{NO}_{2}$ and $\mathrm{PM}_{10}$ particulates is reflected in the higher recession rates of the limestone in the traffic hot spots of both Munich and Mainz with higher $\mathrm{NO}_{2}$ and $\mathrm{PM}_{10}$. Such a study is lacking for London but required to draw better conclusions on the long-term deterioration of Portland limestone.

Higher humidity and rainfall in Munich results in a higher recession rate of Portland limestone as compared to Mainz [29]. Relative humidity is another important factor that needs to be considered as it controls the deposition velocity of $\mathrm{SO}_{2}$ on building surfaces along with atmospheric concentration and must also affect the deposition of nitrogen oxides and other particulate matter, but notably is overlooked in current studies. As discussed in the previous section, the decay of Portland limestone as a consequence of gypsum formation can be enhanced in London due to predicted wetter winters. Gypsum has a comparatively lower solubility and shows little migration, often accumulating in the pore space [82]. However, with higher moisture and rainfall conditions, there will be an increased solubility and migration of the less soluble gypsum [88], a small amount of which will be re-diluted. Following crystallisation in the fissures or interstitial areas at grain contacts, there is an induction of stress in the construction due to high crystallisation pressure [49]. With less severe winters, mechanical decay processes, such as frost weathering, are retarded, as is evident from the decrease in the annual number of the predicted freeze-thaw cycles in the long term up to 2100 [89]. However, moisture dilatation can be more active under the wetter conditions. This can have a feedback effect as moisture dilatation is intensified in the presence of salts and irreversible in contrast to salt-free systems, accelerating further deterioration as scaling, flaking and crumpling [90]. Such processes of salt crystallisation and moisture dilatation will be seen in other rocks, too, including sandstone and granite, but not adequately investigated although the long term trend of salt weathering for London, estimated on the basis that predicted thenardite-mirabilite, exceeding $10 \mathrm{MPa}$, clearly indicate an increasing effect [89]. Furthermore, if stones are wetter, the possibility of the freeze-thaw cycling being more effective, cannot be ruled out.

With continued cycles of hydration/salt migration/crystallisation, there will be increased salt penetration and crystallisation in the pore spaces (crypto efflorescence) leading to progressive deterioration. The extent of damage is more profound in the case of crypto efflorescence when compared to efflorescence, the latter being only confined to the surface. Only if the rate of rehydration from within exceeds the rate of water evaporation from the surface, efflorescence will be observed as the surface remains hydrated and evaporation from the surface will continue to take place [88]. Relative humidity $<75 \%$ can escalate crystallisation-hydration cycles, so drier, hotter summers in London in the future can be a potential threat, especially for carbonate and sandstone but no estimate is yet available related to their correlation.

Increased moisture content will translate to greater depth of wetting front, with penetration known to exceed a depth of $25 \mathrm{~cm}$ in a sandstone rock [91]. With longer and consequent deeper wetting, ion diffusion will become a prominent mechanism shifting emphasis to chemical rather than physical damage, related to salt weathering [62]. However, the delay in the onset of crystallisation as salt remains in solution for longer periods during the prolonged winter wetness, versus the exaggerated and accelerated material decay when it finally occurs after the onset of crystallisation has not yet been assessed. In addition, further studies are required on whether increasing surface moisture will encourage colonisation by algae and other biological agents [92], further aiding in moisture retention at and below the surface [62] for various rock types. Focus should also be given to the specification and application of appropriate mortar, which are more resistant to thermal and moisture changes in an acidic urban environment, to be used in conjunction with flint, slate and bricks in London. 
Finally, it remains to be seen in future studies if stone units in masonry should be replaced by concrete blocks, timber or cast stone features that replicate the appearance of natural stone. Such modern substitute materials, while well covered by standards and tests, do not always weather in the same way as natural stone. This can lead to detrimental aesthetic effects and building performance failure. These materials should be replaced on a "like-for-like" basis, using the same type of stones as the original construction or a replacement that is petrographically similar and compatible. Any replacement should consider holistic heritage values in addition to the potential decay of the building material over time.

\section{Monitoring Building Stones for Deterioration}

The key to long-term preservation of building stones is regular monitoring and maintenance to take timely intervention or replacement to reverse, minimise and arrest further deterioration (Figure 10). Some key methods for monitoring are discussed below.

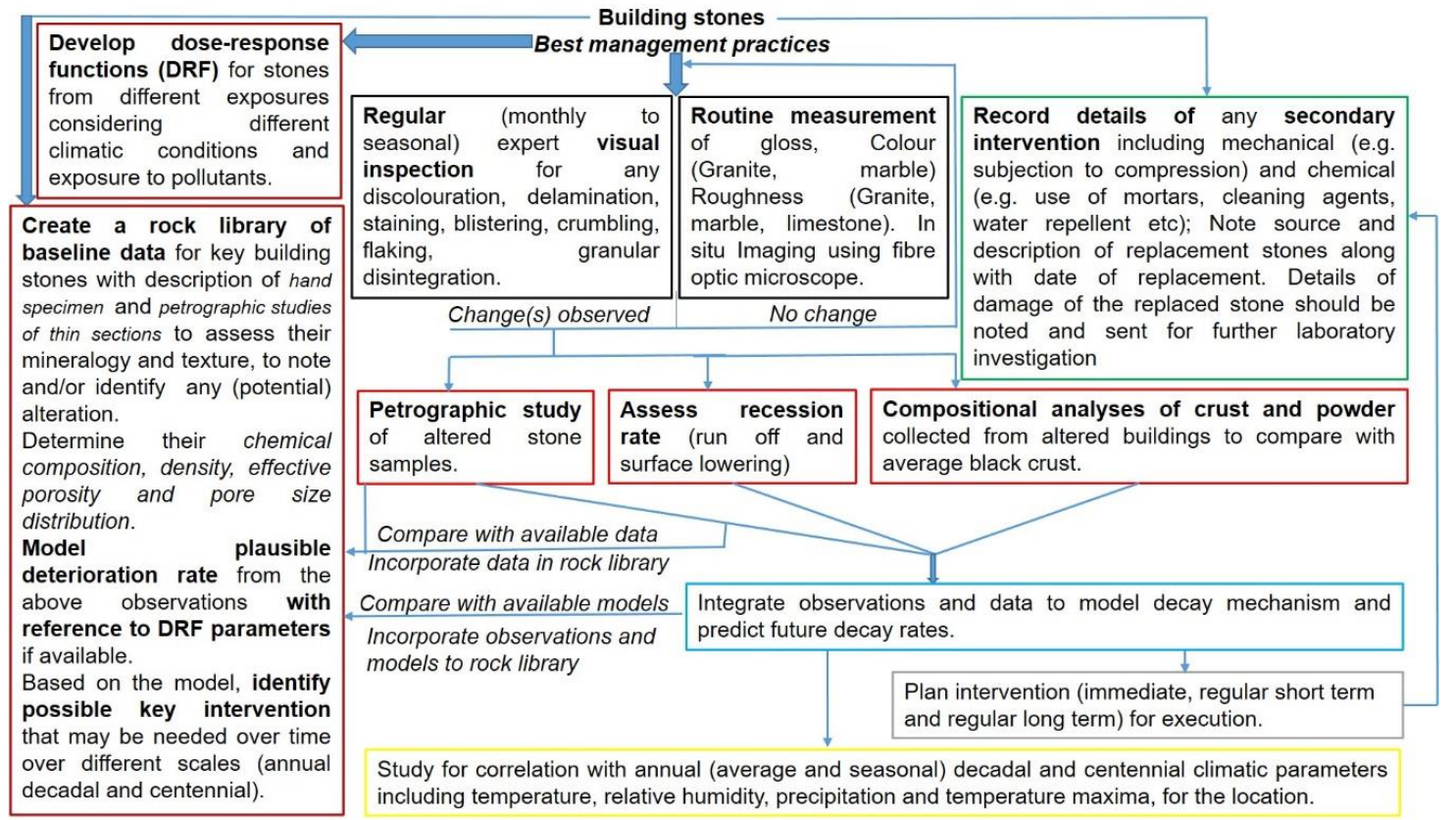

Figure 10. Best management practices for assessment and preservation of building stone deterioration with time.

\subsection{Visual Inspection}

To assess if a building stone has been affected by weathering, it is important to visually inspect for evidences of deterioration such as blistering, crumbling and flaking, granular disintegration, discolouration (commonly reddening, darkening and general deepening of the original colour), surficial staining (commonly orange or brown related to iron oxide from rusting; blue green streaking from copper carbonate and copper sulphate run off; bright to very dark green related to algal growth) [84]. Deterioration can also be identified on the basis of any change in colour and texture in comparison with the sample from the same quarry, when possible. Any damage observed needs to be categorised to identify the best intervention. For example, a noticeable crack of width 5 to $15 \mathrm{~mm}$ or a series of them of $\sim 3 \mathrm{~mm}$ can require superficial repair with limited reconstruction [93]. On the other hand, when cracking is more severe with a width of $15-25 \mathrm{~mm}$, considerable replacement and reconstruction may be involved. Visual inspection by the naked eye can be complemented by a magnifying glass inspection. In situ, high resolution (up to 600× magnification) and contrasted images can be obtained using a fibre optic microscope. This requires no surface preparation but can be used to 
assess any preliminary decay based on the information on the surface texture and morphology, as well as evaluation of cleaning and consolidation interventions [94].

Roughness, gloss and colour are the other key properties to assess surface decay of building stones like marble and granite $[33,49,51]$. Weathered granite shows noticeable colour variation, a higher surface roughness and lower gloss [51]. A detailed, visual inspection can also be combined with the use of contact surface analysis devices and glossmeters [33]. An increase in surface roughness in a limestone also indicates deterioration, as it is related to the solution of the calcite [49]. There are several ways of conducting these measurements, including using a hand profilometer and 3D laser scanning [95].

\subsection{Optical Microscopy and Other Imaging Techniques}

Petrographic analyses involving study of thin sections can be very informative. For limestones, the distribution of the bioclasts, matrix and cement can be used to assess crystallinity. For granite, it can be used to identify kaolinization and sericitisation and, therefore, the impacts of chemical weathering, as well as fissurisation in quartz and feldspar to look at any alteration related to stress-related physical weathering. For slate, the identification of inclusions can be a clue to any potential oxidation. Petrographic studies can be complemented with scanning electron microscopy to aid in close visualisation of individual minerals and micro computed X-ray tomography (micro-CT) to give 3D information about the structure and distribution of the metallic minerals [70].

\subsection{Mineralogical and Geochemical Methods}

Powder X-ray diffraction (XRD) for mineralogical composition and fluorescence (XRF) for chemical composition, coupled with scanning electron microscopy or energy-dispersive $X$-ray spectroscopy (SEM-EDX), can be used for assessing potential deterioration in building stones. Such elemental-mineralogical composition, correlated with imaging, can indicate alteration related to changes in the fabric, such as enhancement in the porosity of a building rock. Analysing the powder deposit collected from stone surfaces can be informative: the inorganic and carbonaceous fractions of limestone can be used to monitor the soluble salt content. This will not only help to constrain the degradation mechanism but can also correlate to the source of the accumulated particulate matter [44]. Care should be exercised to distinguish any depletion of atmospheric particulate matter, such as nitrate in the analysed powder, to the source with deeper migration of pollutants into the stone structure through ion exchange reaction in the presence of moisture or rainwater. Analyses of the powder can employ techniques such as XRD and Fourier transform infrared (FTIR) spectroscopy. XRD and FTIR can also identify if a sulphation process is still active as a result of the interaction between the stones and the atmospheric $\mathrm{SO}_{2}$ pollutants [95].

In a dolomitic limestone, the dolomite/gypsum ratio can be determined to constrain the decay extent of the stone material as a function of sulphation degree, with value $<2$, indicating a higher degree of alteration [75]. For silicate building stones, the depletion associated with silicate phases $\left(\mathrm{SiO}_{2}, \mathrm{Al}_{2} \mathrm{O}_{3}, \mathrm{Na}_{2} \mathrm{O}, \mathrm{K}_{2} \mathrm{O}\right)$, correlated with an increase in sulphates, can be an indicator of the degree of decay [49]. The detection of other chemical ions in the stone samples can indicate presence of secondary pollutants (e.g., oxalates) or application of non-documented treatment to the stones. Analyses of the powder should be routinely compared to that of the reported values for black crust in order to understand if the incoherent powder deposits will eventually evolve into black crusts.

\subsection{Other Attributes}

The measurement and comparison of physical parameters such as ultrasonic velocity, bulk density, open porosity and water absorption of crystalline rocks such as granite and limestone can be useful [50]. Non-destructive moisture measurement, indicating the distribution of moisture, is often used as a broad indicator of any decay mechanism related to water transfer. The differences found in these parameters between the construction stones and the same rocks in the quarry can indicate any decay of 
the stones. The density of a rock is directly correlated to its compressibility strength as well its hardness. Although that may not be necessarily related to the durability, the maximum density as in a limestone of $2.74 \mathrm{~g} / \mathrm{cc}$, corresponds to a pure, un-porous limestone [79]. In such a variety, with limited pore spaces for circulating fluids and moisture absorption, there will be minimal decay and higher durability. The crystallinity and the compactness of the rock can be assessed on the basis of the ultrasonic velocity while lower porosity can be related to lower accessibility to water and water absorption. In marble too, reduction in the ultrasonic velocity is accompanied by an advancement in the weathering front, with a decrease in the mechanical strength and the Young's modulus [56]. The moisture response of the building stones should be tested both in the presence of hygric moisture (related to relative humidity) and hydric moisture (under water immersion).

Dose-response functions (DRF), expressed as surface recession due to the prevailing attack of $\mathrm{SO}_{2}$ and its secondary products, can be used for monitoring by comparing with data available for standard material, such as Portland limestone [96] which is a widely used building stone for a number of London heritage sites. DRF can be used for assessment in the context of both former and future pollution loads. Considering the decreased $\mathrm{SO}_{2}$ concentration, the relative influence of other pollutants has to be considered from a multi-pollutant situation in future studies [29].

\section{Conclusions}

The predicted changes in the UK climate, especially pronounced for London, indicate warmer and wetter winters, hotter drier summers with increase in summer temperature maxima, extreme rainfall events and higher annual precipitation with a decline in summer but an increase during winter. Such phenomenon will affect the decay of the common building stones used in the heritage sites of London. The deterioration mechanisms and monitoring methods discussed here are not limited to London, but are transferrable to other urban contexts too, although consideration should be given to regional climate variation.

The dissolution of carbonate minerals in limestone will be enhanced due to the predicted increase in precipitation and the rising concentration of air pollutants, such as nitrogen oxides, which may also accumulate as dry deposits on the stone surfaces to be later mobilised by subsequent rainfall. This results in near-surface sulphate crystallisation and efflorescence that leads to exfoliation and crumpling by powder formation, which contributes to the development of internal stresses in the rock mass. Any immature sandstone, such as litharenite, with high porosity and bimodal pore distribution is prone to salt weathering as capillary water uptake and moisture absorption are facilitated by the micropores present. Salt transportation occurs by ion diffusion that is likely to be more pronounced in the future in London due to the wetter, winter months and higher annual precipitation. Due to the prolonged wet winters, the saline solution circulates and interacts extensively with the rock matrix and cement, weakening it considerably, even before the onset of the salt crystallisation. More significantly, for predicted $\mathrm{CO}_{2}$ concentration of up to $750 \mathrm{ppm}$ by 2099 and decline in traditional air pollutants, 96 to $99.5 \%$ of surface recession of carbonate stones can be due to karst effect.

In contrast, marble that deteriorates mostly by microcracking, as cooling is expected to decline with time, will not be as adversely affected (as with the limestone and the sandstone). Any granitic building stone will also remain unaffected due to the expected continued decline of $\mathrm{SO}_{2}$ concentration with time in London that should reduce the incidence of kaolinisation. Microcracking of feldspars will be greatly reduced too, due to the predicted wetter and warmer winters in London that will lead to a decrease in any freeze-thaw processes. Consequently, access pathways of fluid flow and air pollutants will be limited, thereby further reducing the possibility of kaolinisation and sericitisation. Flint and slate, as well as the red bricks, commonly used as building stones in London will not be significantly affected by predicted climate change. However, care should be taken with the use of mortar that will be required to be more resistant to thermal and moisture changes. Additionally, any mineral impurities that may be present should be noted. As an example, any pyrite in the slate will be more susceptible to oxidation under higher rainfall leading to the deposition of iron sulphate salts. 
In the future, studies on London building stones should focus on the assessment of their recession rates and any influence of emerging air pollutants such as $\mathrm{NO}_{2}$ and $\mathrm{PM}_{10}$ particulates. The role of humidity, and consequently, the effect of hotter, drier summers and warmer, wetter winters in London on the crystallisation-hydration cycles for carbonate and sandstone, needs to be better understood. Under the predicted wetter conditions, the role of moisture dilatation may also be enhanced and requires better understanding.

The best practices for the management of building stones in London, also applicable to other cities, is summarised in Figure 10. It involves regular observations for alteration features and routine measurements of gloss, colour and roughness. This can be complemented with further petrographic studies and chemical analyses as necessary. It would be important to create a rock library with baseline data of mineralogy and chemical composition of the common building stones (Figure 10). Finally, dose-response functions (DRF), for different building stones from different exposures that consider different climatic conditions and exposure to pollutants, should be developed.

Author Contributions: The study was conceptualised and designed by S.B., S.A.O. and Y.D.A. The formal analysis and funding acquisition were carried out by S.B. The visualisation was done by S.B. and S.A.O. The original draft of the manuscript was prepared by S.B and reviewed and edited by S.A.O. and Y.D.A. All authors have read and agreed to the published version of the manuscript.

Funding: This research was funded by UCL Global Engagement Funds 2019/20 award number 177785.

Conflicts of Interest: The authors declare no conflict of interest.

\section{References}

1. Leissner, J.; Fuhrmann, C. Cultural Heritage and Climate Change: Are We at the Tipping Point? Instituto Italiano di Cultura: Brussels, Belgium, 2017; p. 221.

2. Stocker, T.F.; Qin, D.; Plattner, G.K.; Tignor, M.; Allen, S.K.; Boschung, J.; Nauels, A.; Xia, Y.; Bex, V.; Midgley, P.M. (Eds.) Climate Change 2013: The Physical Science Basis: Working Group I Contribution to the Fifth Assessment Report of the Intergovernmental Panel on Climate Change; IPCC 2013; Cambridge University Press: Cambridge, UK, 2013.

3. Field, C.B.; Field, C.B.; Barros, V.; Stocker, T.F.; Dahe, Q. (Eds.) Managing the Risks of Extreme Events and Disasters to Advance Climate Change Adaptation; IPCC 2012; Cambridge University Press: Cambridge, UK, 2012; p. 582.

4. Fookes, P.G.; Lee, E.M. Climate variation: A simple geological perspective. Geol. Today 2007, $23,66-73$. [CrossRef]

5. Lowe, J.A.; Bernie, D.; Bett, P.; Bricheno, L.; Brown, S.; Calvert, D.; Clark, R.; Eagle, K.; Edwards, T.; Fosser, G.; et al. UKCP18 Science Overview Report Version 2.0; Met Office, Hadley Centre: Exeter, UK, 2018; Updated March 2019.

6. Nathanail, J.; Banks, V.J. Climate change: Implications for engineering geology practice. In Geological Society London Engineering Geology Special Publications; Geological Society: London, UK, 2009; Volume 22, pp. 65-82.

7. Viles, H.A. Implications of future climate change for stone deterioration. In Natural Stone, Weathering Phenomena, Conservation Strategies and Case Studies; Geological Society: London, UK, 2002; Volume 205, pp. 407-418.

8. Schneider, T.; O'Gorman, P.A.; Levine, X.J. Water vapor and the dynamics of climate changes. Rev. Geophys. 2010, 48, RG3001. [CrossRef]

9. Satterthwaite, D. Cities' contribution to global warming: Notes on the allocation of greenhouse gas emissions. Environ. Urban. 2008, 20, 539-549. [CrossRef]

10. UN Climate Neutral Strategy. Greening The Blue. 5 June 2007. Available online: https://www.un.org/en/ sections/general/un-and-sustainability/ (accessed on 26 July 2020).

11. Aram, F.; García, E.H.; Solgi, E.; Mansournia, S. Urban green space cooling effect in cities. Heliyon 2019, 5, e01339. [CrossRef]

12. Aktaş, Y.D.; Stocker, J.; Carruthers, D.; Hunt, J. A Sensitivity Study Relating to Local Urban Climate Modelling within the Built Environment. Procedia Eng. 2017, 198, 589-599. [CrossRef] 
13. Hunt, J.C.; Aktas, Y.D.; Mahalov, A.; Moustaoui, M.; Salamanca, F.; Georgescu, M. Climate change and growing megacities: Hazards and vulnerability. Proc. Inst. Civ. Eng. Eng. Sustain. 2017, 171, 314-326. [CrossRef]

14. Paris Agreement under the United Nations Framework Convention on Climate Change. In Proceedings of the 21st Conference of the Parties, Paris, France, 12 December 2015.

15. Siegfried, S.; Brimblecombe, P. Editorial to the Special Issue "urban use of rocks". Environ. Earth Sci. 2013, 69, 1067-1069.

16. Bell, F.G. Durability of carbonate rock as building stone with comments on its preservation. Environ. Geol. 1993, 21, 187-200. [CrossRef]

17. Robinson, E. A Geology of the British Library. Available online: https://www.webarchive.org.uk/wayback/ archive/20100427150116/http:/www.bl.uk/reshelp/experthelp/science/science@blevents/futureevents/ geology_of_the_bl.pdf (accessed on 14 October 2016).

18. Garcia-del-Cura, M.A.; Benavente, D.; Martinez-Martinez, J.; Cueto, N. Sedimentary structures and physical properties of travertine and carbonate tufa building stone. Constr. Build. Mater. 2012, 28, 456-467. [CrossRef]

19. Sabbioni, C.; Bonazza, A.; Zamagni, J.; Ghedini, N.; Grossi, C.M.; Brimblecombe, P. The Tower of London: A case study of stone decay in an urban area. In Air Pollution and Cultural; Saiz, C., Ed.; AA Balkema: London, UK, 2004; pp. 57-62.

20. Building Stones and the Landscape British Geological Survey. Available online: https://www.bgs. ac.uk/discoveringGeology/geologyOfBritain/limestoneLandscapes/resourcesConflictsSustainability/ buildingStones.html (accessed on 7 March 2020).

21. Palmer, T.J. Limestone petrography and durability in English Jurassic freestones. In Proceedings of the England's Heritage Stone: Proceedings of a Conference, Tempest Anderson Hall, York, UK, 15-17 March 2005; pp. 65-78.

22. Ingham, J.P. Predicting the frost resistance of building stone. Q. J. Eng. Geol. Hydrogeol. 2005, 38, 387-399. [CrossRef]

23. Cherblanc, F.; Berthonneau, J.; Bromblet, P. Role of hydro-mechanical coupling in the damage process of limestones used in historical buildings. In Proceedings of the 13th International Congress on the Deterioration and Conservation of Stone, Glasgow, UK, 6-10 September 2016.

24. Morse, J.W.; Arvidson, R.S. The Dissolution Kinetics of Major Sedimentary Carbonate Minerals. Earth Sci. Rev. 2002, 58, 51-84. [CrossRef]

25. Reddy, M.M. Acid rain damage to carbonate stones: A quantitative assessment based on the aqueous geochemistry of rainfall runoff from stone. Earth Surf. Process. Landf. 1988, 13, 335-354. [CrossRef]

26. Grossi, C.M.; Murray, M. Characteristics of carbonate building stones that influence the dry deposition of acidic gases. Constr. Build. Mater. 1999, 13, 101-108. [CrossRef]

27. Cooper, T.P.; O’Brien, P.F.; Jeffrey, D.W. Rates of Deterioration of Portland Limestone in an Urban Environment. Stud. Conserv. 1992, 37, 228-238.

28. Inkpen, R.; Viles, H.; Moses, C.; Baily, B. Modelling the impact of changing atmospheric pollution levels on limestone erosion rates in central London, 1980-2010. Atmos. Environ. 2012, 61, 476-481. [CrossRef]

29. Auras, M.; Beer, S.; Bundschuh, P.; Eichhorn, J.; Mach, M.; Scheuvens, D.; Schorling, M.; Schumann, J.V.; Snethlage, R.; Weinbruch, S. Traffic-related emissions and their impact on historic buildings: Implications from a pilot study at two German cities. Environ. Earth Sci. 2013, 69, 1135-1147. [CrossRef]

30. Lipfert, F.W. Atmospheric damage to calcareous stones: Comparison and reconciliation of recent experimental findings. Atmos. Environ. 1989, 23, 415-429. [CrossRef]

31. Bonazza, A.; Palmira, M.; Sabbioni, C.; Grossi, C.; Brimblecombe, P. Mapping the impact of climate change on surface recession of carbonate buildings in Europe. Sci. Total Environ. 2009, 407, 2039-2050. [CrossRef]

32. Doehne, E. Salt weathering: A selective review. In Geological Society London Special Publication Natural Stone, Weathering Phenomena, Conservation Strategies and Case Studies; Siegesmund, S., Weiss, T., Vollbrecht, A., Eds.; Geological Society of London: London, UK, 2002; Volume 205, pp. 51-64.

33. Gulotta, D.; Bertoldi, M.; Bortolotto, S.; Fermo, P.; Piazzalunga, A.; Toniolo, L. The Angera stone: A challenging conservation issue in the polluted environment of Milan (Italy). Environ. Earth Sci. 2013, 69, 1085-1094. [CrossRef]

34. Smith, B.J.; Viles, H.A. Rapid, catastrophic decay of building limestones: Thoughts on causes, effects and consequences. In Heritage Weathering and Conservation; Taylor and Francis: London, UK, 2003; pp. 191-197. 
35. Török, A. Morphology and detachment mechanism of weathering crusts of porous limestone in the urban environment of Budapest. Cent. Eur. Geol. 2007, 50, 225-240. [CrossRef]

36. Haynie, F.H. Theoretical model of soiling of surfaces by airborne particles in aerosols: Research, risk assessment and Control Strategies. In Proceedings of the Second US-Dutch International Symposium, Williamsburg, VA, USA, 19-4 May 1986; Lee, S.D., Ed.; Lewis Publishers: Williamsburg, VA, USA, 1986.

37. Grossi, C.M.; Esbert, R.M.; Alonso, F.J. Soiling of building stones in urban environments. Build. Environ. 2003, 38, 147-159. [CrossRef]

38. Ascaso, C.; Wierzchos, J.; Souza-Egipsy, V.; de los Rı'os, A.; Delgado, J.; Rodrigues, J. In situ evaluation of the biodeteriorating action of microorganisms and the effects of biocides on carbonate rock of the Jeronimos Monastery (Lisbon). Biodeterior. Biodegrad. 2002, 49, 1-12. [CrossRef]

39. Schiavon, N. Assessment of Building Stone Decay: A Geomorphological Approach. In Proceedings of the International Conference of Stone Cleaning and the Nature, Soiling and Decay Mechanisms of Stone, Edinburgh, UK, 14-16 April 1992; Webster, R.G.M., Ed.; Donhead Publishing: Shaftesbury, UK, 1992.

40. Sterflinger, K.; Piñar, G. Microbial deterioration of cultural heritage and works of art-Tilting at windmills? Appl. Microbiol. Biotechnol. 2013, 97, 9637-9646. [CrossRef] [PubMed]

41. Bonazza, A.; Brimblecombe, P.; Grossi, C.M.; Sabbioni, C. Carbon in black layers at the Tower of London. Environ. Sci. Technol. 2007, 41, 4199-4204. [CrossRef]

42. Eyssautier-Chuine, S.; Marin, B.; Thomachot-Schneider, C.; Fronteau, G.; Schneider, A.; Gibeaux, S.; Vazquez, P. Simulation of acid rain weathering effect on natural and artificial carbonate stones. Environ. Earth Sci. 2016, 75, 748. [CrossRef]

43. Hallmann, C.; Stannek, L.; Fritzlar, D.; Hause-Reitner, D.; Friedl, T.; Hoppert, M. Molecular diversity of phototrophic biofilms on building stone. FEMS Microbiol. Ecol. 2013, 84, 355-372. [CrossRef]

44. Vázquez, P.; Luque, A.; Alonso, F.J.; Grossi, C.M. Surface changes on crystalline stones due to salt crystallisation. Environ. Earth Sci. 2013, 69, 1237-1248. [CrossRef]

45. Shushakova, V.; Fuller, E.R., Jr.; Heidelbach, F.; Mainprice, D.; Siegesmund, S. Marble decay induced by thermal strains: Simulations and experiments. Environ. Earth Sci. 2013, 69, 1281-1297. [CrossRef]

46. Fort, R.; Varas, M.J.; de Buergo, M.A.; Martin-Freire, D. Determination of anisotropy to enhance the durability of natural stone. J. Geophys. Eng. 2011, 8, S132-S144. [CrossRef]

47. Goudie, A.S. Laboratory simulation of the 'wick effect' in salt weathering of rock. Earth Surf. Process. Landf. 1986, 11, 275-285. [CrossRef]

48. Schiavon, N. Kaolinisation of granite in an urban environment. Environ. Geol. 2007, 52, 399-407. [CrossRef]

49. Graue, B.; Siegesmund, S.; Oyhantcabal, P.; Naumann, R.; Licha, T.; Simon, K. The effect of air pollution on stone decay: The decay of the Drachenfels trachyte in industrial, urban, and rural environments-A case study of the Cologne, Altenberg and Xanten cathedrals. Environ. Earth Sci. 2013, 69, 1095-1124. [CrossRef]

50. Perez-Monserrat, E.M.; de Buergo, M.A.; Gomez-Heras, M.; Muriel, M.J.V.; Gonzalez, R.F. An urban geomonumental route focusing on the petrological and decay features of traditional building stones used in Madrid, Spain. Environ. Earth Sci. 2013, 69, 1071-1084. [CrossRef]

51. Sousa, L.M.O. The influence of the characteristics of quartz and mineral deterioration on the strength of granitic dimensional stones. Environ. Earth Sci. 2013, 69, 1333-1346. [CrossRef]

52. Gomez-Heras, M.; Smith, B.J.; Fort, R. Influence of surface heterogeneities of building granite on its thermal response and its potential for the generation of thermoclasty. Environ. Geol. 2008, 56, 547-560. [CrossRef]

53. Wilson, M.J. Weathering of the primary rock-forming minerals: Processes, products and rates. Clay Miner. 2004, 39, 233-266. [CrossRef]

54. Gräf, V.; Jamek, M.; Rohatsch, A.; Tschegg, E. Effects of thermal-heating cycle treatment on thermal expansion behavior of different building stones. Rock Mech. Min. Sci. 2013, 64, 228-235. [CrossRef]

55. Freire-Lista, D.M.; Fort, R.; Varas-Muriel, M.J. Thermal stress-induced microcracking in building granite. Eng. Geol. 2016, 206, 83-93. [CrossRef]

56. Ruedrich, J.; Kirchner, D.; Seidel, M.; Siegesmund, S. Deterioration of natural building stones induced by salt and ice crystallisation in the pore space as well as hygric expansion processes. In Geowissenschaften und Denkmalpflege. Zeitschrift Deutsche Geologische Gesellschaft; Siegesmund, S., Auras, M., Ruedrich, J., Snethlage, R., Eds.; Schweizerbart Science Publishers: Stuttgart, Germany, 2005; Volume 156/1, pp. 59-73.

57. Wellmann, H.W.; Wilson, A.T. Salt Weathering, a Neglected Geological Erosive Agent in Coastal and Arid Environments. Nature 1965, 205, 1097-1098. [CrossRef] 
58. Ruedrich, J.; Knell, C.; Enseleit, J.; Rieffel, Y.; Sigesmund, S. Stability assessment of marble statuaries of the Schlossbrucke (Berlin, Germany) based on rock strength measurements and ultrasonic wave velocities. Environ. Earth Sci. 2013, 69, 1451-1469. [CrossRef]

59. Stück, H.; Koch, R.; Siegesmund, S. Petrographical and petrophysical properties of sandstones: Statistical analysis as an approach to predict material behaviour and construction suitability. Environ. Earth Sci. 2013, 69, 1299-1332. [CrossRef]

60. Godts, S.; Hayen, R.; De Clercq, H. Investigating salt decay of stone materials related to the environment, a case study in the St. James church in Liège, Belgium. Stud. Conserv. 2017, 62, 329-342. [CrossRef]

61. Charola, A.E.; Pühringer, J.; Steiger, M. Gypsum: A review of its role in the deterioration of building materials. Environ. Geol. 2007, 52, 339-352. [CrossRef]

62. Stück, H.; Plagge, R.; Siegesmund, S. Numerical modeling of moisture transport in sandstone: The influence of pore space, fabric and clay content. Environ. Earth Sci. 2013, 69, 1161-1187. [CrossRef]

63. McCabe, S.; Smith, B.J.; McAlister, J.J.; Gomez-Heras, M.; McAllister, D.; Warke, P.A.; Curran, J.M.; Basheer, P.A.M. Changing climate, changing process: Implications for salt transportation and weathering within building sandstones in the UK. Environ. Earth Sci. 2013, 69, 1225-1235. [CrossRef]

64. Sebastián, E.; Cultrone, G.; Benavente, D.; Fernandez, L.L.; Elert, K.; Rodriguez-Navarro, C. Swelling damage in clay-rich sandstones used in the church of San Mateo in Tarifa (Spain). J. Cult. Herit. 2008, 9, 66-76. [CrossRef]

65. Smith, B.J.; Turkington, A.V.; Warke, P.A.; Basheer, P.A.M.; McAlister, J.J.; Meneely, J.; Curran, J.M. Modelling the rapid retreat of building sandstones: A case study from a polluted maritime environment. In Natural Stone, Weathering Phenomenon, Conservation Strategies and Case Studies; Seigesmund, S., Weiss, T., Vollbrecht, A., Eds.; Geological Society: London, UK, 2002; Volume 205, pp. 347-362.

66. Caneva, G.; Nugari, M.P.; Salvadori, O. Biology in the Conservation of Works of Art; ICCROM: Roma, Italy, 1991.

67. Jain, A.; Bhadauria, S.; Kumar, V.; Chauhan, R.S. Biodeterioration of sandstone under the influence of different humidity levels in laboratory conditions. Build. Environ. 2009, 44, 1276-1284. [CrossRef]

68. Bjell, T.; Thorseth, I.H. Comparative studies of the lichen-rock interface of four lichens in Vingen, western Norway. Chem. Geol. 2002, 192, 81-98. [CrossRef]

69. Tiennot, M.; Mertz, J.-D.; Bourgès, A. Influence of Clay Minerals Nature on the Hydromechanical and Fracture Behaviour of Stones. Rock Mech. Rock Eng. 2019, 52, 1599-1611. [CrossRef]

70. Ashurst, J.; Williams, G.; Bourgès, A. Flint and the Conservation of Flint Buildings. The Building Conservation Directory. 2005. Available online: https:/www.buildingconservation.com/articles/flint/flint.htm (accessed on 7 May 2020).

71. Cardenes, V.; Cnuddle, V.; Cnuddle, J.P. Petrography of roofing slate for quality assessment. In Proceedings of the 15th Euroseminar on Microscopy Applied to Building Materials, Delft, The Netherlands, 17-19 June 2015.

72. Cárdenes, V.; Rubio-Ordonez, A.; Monterroso, C.; Calleja, L. Geology and geochemistry of Iberian roofing slates. Geochemistry 2013, 73, 373-382. [CrossRef]

73. Gómez-Fernández, F.; Castaño, M.A.; Bauluz, B.; Ward, C.R. Optical microscope and SEM evaluation of roofing slate fissility and durability. Mater. De Construcción 2009, 59, 91-104.

74. Demarco, M.M.; Oyhantcabal, P.; Stein, K.M.; Siegesmund, S. Dolomitic slates from Uruguay: Petrophysical and petromechanical characterization and deposit evaluation. Environ. Earth Sci. 2013, 69, 1361-1395. [CrossRef]

75. Siedel, H. Magnesium sulphate salts on monuments in Saxony (Germany): Regional geological and environmental causes. Environ. Earth Sci. 2013, 69, 1249-1261. [CrossRef]

76. Szemerey-Kiss, B.; Török, A.; Siegesmund, S. The influence of binder/aggregate ratio on the pore properties and strength of repair mortars. Environ. Earth Sci. 2013, 69, 1439-1449. [CrossRef]

77. Henry, A.; McCaig, I.; Willett, C.; Godfraind, S.; Stewart, J. (Eds.) Historic England Practical Building Conservation. In Earth, Brick \& Terracotta; Ashgate/Routledge: Farnham, UK, 2015.

78. Bates, S.J. A Critical Evaluation of Salt Weathering Impacts on Building Materials at Jazirat al Hamra, UAE. Geoverse 2010, 1758-3411. Available online: http://geoverse.brookes.ac.uk/article_resources/batesSJ/batesSJ. htm (accessed on 9 July 2020).

79. Bide, T.P.; Barron, A.J.M.; Evans, D.J. An Assessment of the Aggregate Properties of the Lower Lincolnshire Limestone in South Lincolnshire and Surrounding Areas; British Geological Survey Commissioned Report: CR/15/083; Keyworth, Nottingham British Geological Survey: Nottingham, UK, 2015; 22p. 
80. Palmer, T.J. Understanding the Weathering Behaviour of Caen Stone. J. Archit. Conserv. 2008, 14, 45-54. [CrossRef]

81. Historic England Strategic Stone Study A Building Stone Atlas of East Sussex. Available online: https: //www.southdowns.gov.uk/wp-content/uploads/2016/12/East_Sussex_Building_Stone_Atlas.pdf (accessed on 7 May 2020).

82. Lott, G.K.; Cooper, A.H. Field guide to the building limestones of the upper Permian Cadeby formation (magnesian limestone) of Yorkshire. In Proceedings of the England's Heritage Stone: Proceedings of a Conference, Tempest Anderson Hall, York, UK, 15-17 March 2005; pp. 80-89.

83. Lott, G.K.; Richardson, C. Yorkshire stone for building the Houses of Parliament (1839-1852). Proc. Yorks. Geol. Soc. 1997, 51, 265-272. [CrossRef]

84. Heritage, E. English Heritage Practical Building Conservation Stone; Odgers, D., Henry, A., Eds.; Ashgate/Routledge: Farnham, UK, 2012.

85. Michette, M.; Viles, H.; Vlachou-Mogire, C.; Angus, I. Assessing the Long-term Success of Reigate Stone Conservation at Hampton Court Palace and the Tower of London. Stud. Conserv. 2020, 1-8. [CrossRef]

86. Wiese, U.; Behlen, A.; Steiger, $\mathrm{M}$. The influence of relative humidity on the $\mathrm{SO}_{2}$ deposition velocity to building stones: A chamber study at very low $\mathrm{SO}_{2}$ concentration. Environ. Earth Sci. 2013, 69, 1125-1134. [CrossRef]

87. Fuchs, G. Allgemeine Mikrobiologie; Georg Thieme: Stuttgart, Germany, 2006; pp. 321-340.

88. Colston, B.J.; Watt, D.S.; Munro, H.M. Environmentally-induced stone decay: The cumulative effects of crystallization-hydration cycles on a Lincolnshire oopelsparite limestone. J. Cult. Herit. 2001, 4, 297-307. [CrossRef]

89. Brimblecombe, P.; Grossi, C.M. Millennium-long recession of limestone facades in London. Environ. Geol. 2008, 56, 463-471.

90. Snethlage, R.; Wendler, E. Moisture cycles and sandstone degradation. In Saving Our Architectural Heritage: Conservation of Historic Stone Structures; Baer, N.S., Snethlage, R., Eds.; John Wiley and Sons Ltd.: London, UK, 1997; pp. 7-24.

91. McAllister, D.; McCabe, S.; Srinivasan, S.; Smith, B.J.; Warke, P.A. Moisture dynamics in building sandstone: Monitoring strategies and implications for transport and accumulation of salts. In Salt Weathering on Buildings and Stone Sculptures 2011; Ioannou, I., Theodoridou, M., Eds.; University of Cyprus: Nicosia, Cyprus, 2011; pp. 39-46.

92. Cutler, N.; Viles, H. Eukaryotic microorganisms and stone biodeterioration. Geomicrobiol. J. 2010, 27, 630-646. [CrossRef]

93. Ellison, R.A.; McMillan, A.A.; Lott, G.K. Ground Characterisation of the Urban Environment: A Guide to Best Practice; Research Report RR/02/05; British Geological Survey: Keyworth, Notthingham, 2002; p. 37.

94. Menéndez, B. Non-Destructive Techniques Applied to Monumental Stone Conservation. Non-Destr. Test 2016. [CrossRef]

95. Tambe, S.; Gauri, K.L.; Li, S.; Cobourn, W.G. Kinetic study of sulfur dioxide reaction with dolomite. Environ. Sci. Technol. 1991, 25, 2071-2075. [CrossRef]

96. Watt, J.; Jarrett, D.; Hamilton, R. Dose-response functions for the soiling of heritage materials due to air pollution exposure. Sci. Total Environ. 2008, 400, 415-424. [CrossRef] [PubMed]

(C) 2020 by the authors. Licensee MDPI, Basel, Switzerland. This article is an open access article distributed under the terms and conditions of the Creative Commons Attribution (CC BY) license (http://creativecommons.org/licenses/by/4.0/). 